Research paper

\title{
Climatic control on stacking and connectivity of fluvial successions: Upper Cretaceous Bajo Barreal Formation of the Golfo San Jorge basin, Patagonia
}

\author{
José Matildo Paredes ${ }^{\mathrm{a}, *}$, Sergio Roberto Giordano ${ }^{\mathrm{b}}$, Sabrina Ximena Olazábal ${ }^{\mathrm{a}}$, \\ Mauro Nicolás Valle ${ }^{\mathrm{a}, \mathrm{c}}$, José Oscar Allard ${ }^{\mathrm{a}}$, Nicolás Foix ${ }^{\mathrm{a}, \mathrm{c}}$, Maisa Andrea Tunik ${ }^{\mathrm{c}, \mathrm{d}}$ \\ ${ }^{a}$ Universidad Nacional de la Patagonia San Juan Bosco, Ruta No 1 S/N, Km 4 (9005), Com. Riv., Chubut, Argentina \\ ${ }^{\mathrm{b}}$ SINOPEC ARGENTINA E\&P, Inc., Manuela Saenz 323, C1107BPA, Buenos Aires, Argentina \\ ${ }^{\mathrm{c}}$ CONICET (Consejo Nacional de Investigaciones Científicas y Técnicas), Argentina

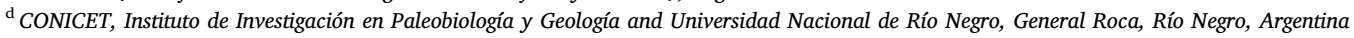

\section{A R T I C L E I N F O}

\section{Keywords:}

Outcrop gamma-ray spectra

Chemical weathering

Kaolinite variation

Detrital provenance changes

Humid climate

Upper Cretaceous

Patagonia

\begin{abstract}
A B S T R A C T
Climate impact on alluvial organization owing to its control on water availability and sediment delivery within the catchment, but temporal changes in stacking patterns are often interpreted to reflect changes in subsidence and base level. To test for evidence of climatic control on the stacking pattern, we study an outcrop succession with two styles of stacking within the Upper Cretaceous Bajo Barreal Formation in the Cerro Ballena anticline, Golfo San Jorge Basin, Argentina. The $385 \mathrm{~m}$ thick and $2.5 \mathrm{~km}$ wide exposure has layer-cake geometry, lacking either large-scale erosional surfaces, fluvial terraces, or evident paleosols, dismissing either local tectonic activity or base-levels shifts. Rooted in a paleohydrological study recognizing upward increasing in both channel width and flow depth of formative rivers, we use spectral gamma-ray logs, x-ray diffraction in mudstones, and sandstone petrography to understand the controls on the stacking pattern. At the base, Section A consists of small-scale, isolated channels fills in a siliciclastic floodplain with sand:mud ratio of $\sim 1: 6$, whereas the overlying Section $\mathrm{B}$ has a sand-mud ratio of $\sim 1: 3$, with larger-scale channels and greater inter-connectivity within a volcaniclastic floodplain. Upward reduction in K percentage through Section A parallel with increasing kaolinite content, and mudstone samples from Section B contains a higher proportion of kaolinite than Section A samples, evidencing an upward increase in paleo-weathering in humid conditions. Detrital components of Section A indicate several volcanic sources (e.g., basic-intermediate components derived from the Middle Jurassic Bahía Laura Group and acidic components sourced from the Andes Cordillera), whereas Section B exclusively contains acidic clasts derived from the Andes Cordillera. Simultaneous changes in detrital constituents, suspended load type, and increasing scale of the rivers in Section B occur coeval with increases in channel inter-connectivity, here related to the increase of river discharge and sediment supply in a humid climate, favoring more frequent avulsions or higher channel migration rates in a relatively flat geomorphic scenario. The study demonstrates, combining independent lines of evidence, that climate change can impact the stacking and connectivity of potential sandstone reservoirs.
\end{abstract}

\section{Introduction}

Ancient fluvial systems contain significant hydrocarbon accumulations on many continental basins, representing up to $20 \%$ of the remaining reserves of hydrocarbons of the world. Advances in the understanding of fluvial successions come from several inter-related disciplines, as 3-D seismic surveys (Posamentier et al., 2007; Ethridge and Schumm, 2007; Reijenstein et al., 2011) modelling studies (Karssenberg et al., 2001; Hajek and Wolinsky, 2012; Keogh et al., 2014; Chamberlin and Hajek, 2015) and field-based studies
(Labourdette, 2011; Allen et al., 2014; Ghinassi et al., 2016, among others). Outcrop analogs contribute to a better understanding of the controls on the alluvial organization and evolution of coeval fluvial reservoirs by analyzing changes in the alluvial architecture, channelscale stacking styles and relationship with adjacent floodplain facies (Pranter and Sommer, 2011; Rittersbacher et al., 2014; Pranter et al., 2014; Paredes et al., 2016). Notably, changes in stacking styles (e.g., isolated versus densely amalgamated channel belts) constitute a common feature identified both in outcrops and subsurface, commonly used to assess relative aggradation rates in fluvial successions (Allen,

\footnotetext{
* Corresponding author.

E-mail addresses: paredesjose@yahoo.com, paredesj@unpata.edu.ar (J.M. Paredes).
} 
1978; Bridge and Leeder, 1979). Those changes are generally related to changes in the ratio of accommodation to sediment supply (Wright and Marriott, 1993; Shanley and McCabe, 1994; Olsen et al., 1995; Kjemperud et al., 2008), although mentions to other variables as vegetation types exist (Davies and Gibling, 2010; Davies et al., 2011). Alternatively, Hajek and Heller (2012) pointed out that changes in amalgamation in fluvial successions, and hence connectivity of potential sandstone reservoirs, may result from variations in flow depth and style of the involved rivers, being an autogenic process that might not require coeval changes in subsidence or base level.

To assess paleoclimatic reconstruction of ancient successions, outcrop spectral gamma-ray (SGR) combined with facies analysis and geochemistry proved to be useful (Myers and Wignall, 1987; Ruffell et al., 2003; Ghasemi-Nejad et al., 2010), being also a critical tool to highlight relationships between texture, composition and provenance (North and Boering, 1999; Corbeanu et al., 2001; Evans et al., 2007; Šimíček et al., 2012), and for stratigraphic analysis (Myers and Bristow, 1989; Parkinson, 1996). Outcrop SGR also allows correlating outcrop sections with wire-line data using the vertical variation of $\mathrm{K}, \mathrm{U}$, and $\mathrm{Th}$ (Hampson et al., 2005; Keeton et al., 2015).

The study succession of the Bajo Barreal Formation at Cerro Ballena anticline is a good outcrop analog to subsurface alluvial successions and can be used to test the relative importance of allogenic forcing factors on the alluvial organization and of stacking pattern because it has a scale that is comparable to that of hydrocarbon reservoirs $(2.5 \mathrm{~km}$ wide x $385 \mathrm{~m}$ thick) and has well-exposed facies relationships. A siliciclastic section with isolated, small scale channel bodies at the base (Section A, $180 \mathrm{~m}$ thick sensu Figari et al., 1998) characterize the Cerro Ballena exposures, covered by densely-stacked channel belts encased in a finegrained volcaniclastic floodplain (Section B, $250 \mathrm{~m}$ thick sensu Figari et al., 1998). In this research, we provide results of detailed outcrop SGR logging of the Cerro Ballena exposures, complemented with x-ray diffraction analysis and sandstone petrography within channel fills. These data, integrated with paleo-hydraulical estimations derived from measurements of cross-bed set thickness in channel fill and measurements of channel sizes (Paredes et al., 2018a), aimed at tracing climatically controlled variations in the overall stacking of the fluvial succession. The main purpose of this paper is to understand the stratigraphic organization of the fluvial succession and to discuss the main controls on the stacking pattern. Our key research questions were: What were the first-order controls on the stacking pattern? What evidence is available to assess paleoclimate at the time of deposition? Can the distinctive lithological sections with different stacking patterns be correlated with the subsurface using outcrop SGR logs, and, if so, can the identified log-motifs be linked to any change in the forcing-factors of the fluvial system?

This research shows how a combination of different techniques can be used to better understand the allogenic and autogenic controls on the alluvial architecture and stacking styles of fluvial successions, with implications for oilfield development.

\section{Geological setting}

The Golfo San Jorge basin, located in Central Patagonia between 45 and $47^{\circ} \mathrm{S}$ latitude, has produced approximately 10 billion barrels of oil $\left(1500\right.$ million $\mathrm{m}^{3}$ ) during its more than 100 years of development history, currently providing up to $48 \%$ of the liquid hydrocarbons of the country production (Secretaría de Energía, 2017). Up to $90 \%$ of those hydrocarbons are recovered from coarse-grained facies in channel fills within the Upper Cretaceous Bajo Barreal Formation, and subsurface equivalents.

The Golfo San Jorge basin formed as response to the Gondwana breakup (Uliana et al., 1989; Fitzgerald et al., 1990), with several phases of extensional reactivation during the Cretaceous (Paredes et al., 2018b; Giampaoli, 2019), followed by a process of positive inversion tectonics along the San Bernardo fold belt (Fig. 1), which rose up mainly during Neogene times (Peroni et al., 1995; Homovc et al., 1995).

The initial basin infill is represented by a siliciclastic lacustrine succession included within the Late Jurassic-Early Cretaceous Las Heras Group (Lesta et al., 1980), preserved in active half-grabens, and overlying a Middle-Jurassic volcanic-volcaniclastic sequence known as Bahía Laura Group (Feruglio, 1949) or Lonco Trapial Group (Lesta and Ferello, 1972). The remaining of the Cretaceous sedimentation corresponds to the Late Barremian-Maastrichtian Chubut Group (). Initial sedimentation of the Chubut Group occurred in a wide lake (Pozo D129 Formation, Barremian? to Aptian) which was sourced from the north by fluvial systems within the Matasiete Formation (Paredes et al., 2007; Allard et al., 2015). The fluvial Castillo Formation (Albian) overlies both units, characterized by an elevated content of reworked ash on floodplains and channel fills (Umazano et al., 2012; Paredes et al., 2015), being replaced in the subsurface of the basin by the Mina del Carmen Formation (Lesta, 1968). The overlying Bajo Barreal Formation has been extensively studied because of its prolific hydrocarbon production and remaining potential (Feruglio, 1949; Lesta and Ferello, 1972). Toward the basin margins, the Bajo Barreal Formation is covered by the fluvial Laguna Palacios Formation (Sciutto, 1981) and by Campanian to Maastrichtian deposits of the Lago Colhué Huapi Formation (Casal et al., 2015; Vallati et al., 2016), being subsequently overlaid by marine and continental Cenozoic sedimentary rocks (Fig. 2).

\section{The Bajo Barreal Formation}

Deposition of the Bajo Barreal Formation (Lesta and Ferello, 1972) occurred in an endorheic basin over an area exceeding $150,000 \mathrm{~km}^{2}$, with maximum thickness up to $1300 \mathrm{~m}$. Due to its wide distribution, the paleoenvironment interpretations change across the basin, being represented by lacustrine fan-deltas, volcaniclastic alluvial fans, meandering and braided rivers, and ephemeral rivers (Brown et al., 1982; Barcat et al., 1989; Hechem et al., 1990; Legarreta et al., 1993; Hechem, 1997; Di Benedetto et al., 2006; Umazano et al., 2008; Georgieff et al., 2009). Outcrop analysis along most of the San Bernardo fold belt recognized a Lower Member and an Upper Member, a distinction based on the floodplain composition and the scale of the sandbodies. The Lower Member is characterized by channelized sandstones interbedded with fine-grained (very fine sand-size) tuffaceous strata, whereas the Upper Member is composed of larger-scale, isolated channel sandbodies surrounded by grey siltstones and siliciclastic mudstones (Figari et al., 1990; Rodríguez, 1993). Most sedimentological outcrop studies indicate the occurrence of fluvial systems with considerable discharge variation (Umazano et al., 2008; Paredes et al., 2016) or ephemeral rivers (Hechem, 1994), whereas a palynological assemblage recovered in the subsurface of the basin (Archangelsky et al., 1994) from the Lower Bajo Barreal Formation indicate humid, continental mild to warm climate.

The Cerro Ballena anticline constitutes the western limb of a faulted, plunging anticline, whose axial trace is oriented NNW-SSE (Fig. 3). Figari et al. (1998) established the principal subdivisions of the Bajo Barreal Formation at Cerro Ballena anticline, identifying three main stratigraphic intervals defined according to the occurrence of discontinuities, lithofacies types and stacking patterns, named A, B, and C in ascending order. Exposures of Sections A and B occur in the core and western limb of the Cerro Ballena (Fig. 3) and constitute the main subject of this research, while Section $C$ is partially identified in the southern plunge of the anticline and mainly southward of the Deseado river (Figari et al., 1998).

A detailed characterization of the fluvial succession was provided by Bridge et al. (2000) using photomosaics and detailed sedimentological logs, where measurements of geometry, lithofacies, and spatial distribution of channel bodies provided support for paleo-hydraulic reconstructions, complemented with a line drawing of internal surfaces of 


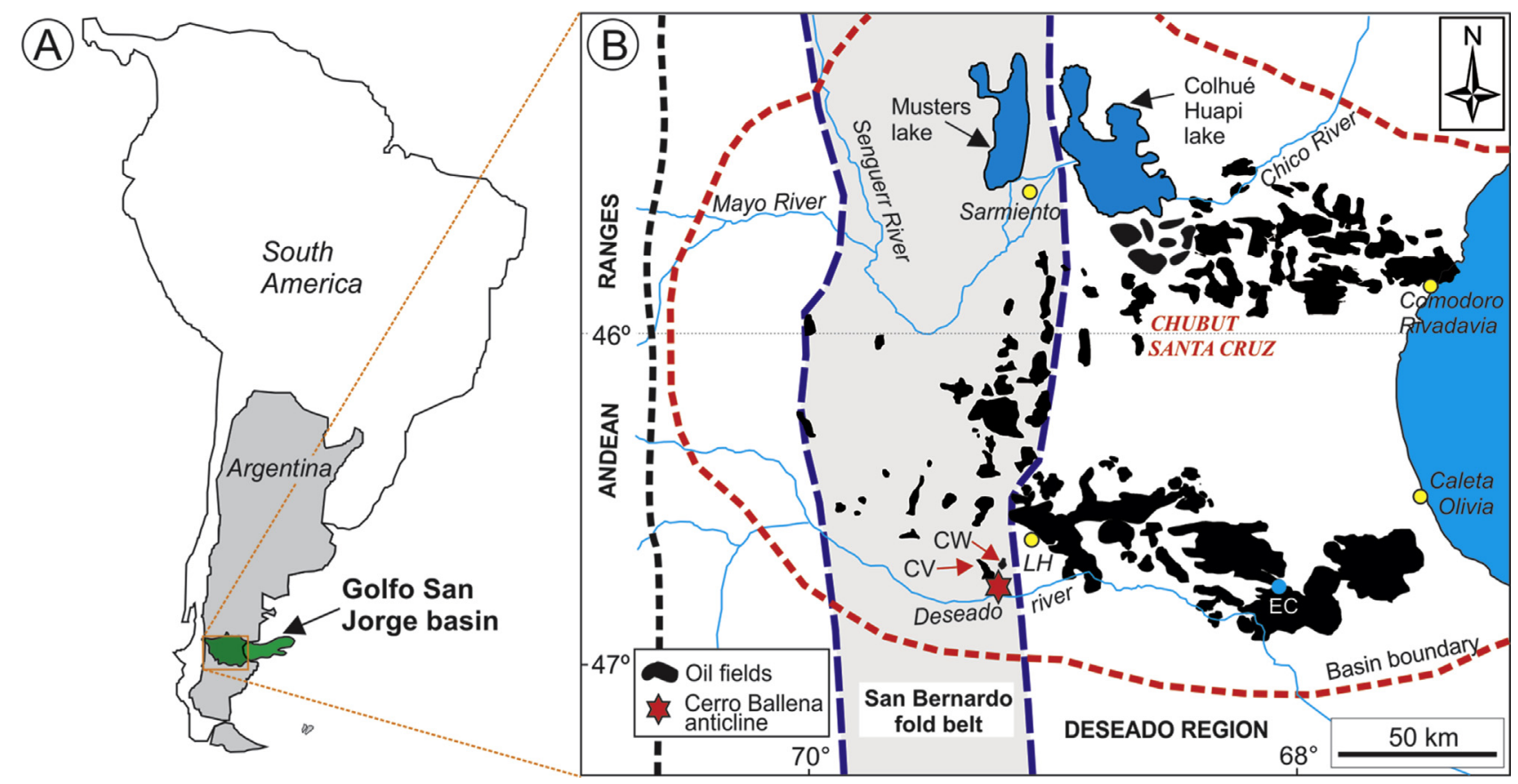

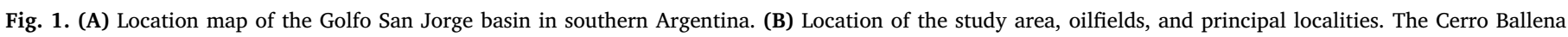
anticline (star) is located in the San Bernardo fold belt area. LH = Las Heras city; CV= Cañadón Vasco oilfield. EC = El Cordón oilfield.

selected sandbodies. They also provided an Ar/Ar age of $91 \pm 0.49 \mathrm{Ma}$ from a distinctive level that separates Sections A and B, interpreted as an ignimbrite (Bridge et al., 2000).

In a recent re-evaluation of the Cerro Ballena exposures, Paredes et al. (2018a) interpreted an anabranching fluvial system with seven distinctive fluvial styles, considerable spatio-temporal variation in channel geometries and dominance of avulsion deposits (Fig. 5). Paredes et al. (2018a: their Fig. 14) identified a systematic vertical (temporal) increase in single-channel dimensions of the formative rivers through Section A and B using GPS measurements on extremes of the channels (see Fig. 5B). Data using empirical equations derived from modern rivers (Leclair and Bridge, 2001; Leclair, 2002; Bridge and Tye, 2000; Bridge and Mackey, 1993) also allowed identify an increase in both average flow depth (dm), mean bankfull channel depth (db), and mean bankfull channel width of single channels (Wc) from Section A to Section B (Fig. 5B), with values of Wc very close to those obtained using GPS measurements of width of single channels (Paredes et al., 2018a: their Table 2). Converging results of both measurements of singlechannel dimensions and use of empirical relations derived from set thickness of cross-beds within channel fills were considered as supporting evidence of discharge increase towards Section B, a trend that was associated with a climatic shift toward more humid climatic conditions (Paredes et al., 2018a). Based on current understanding, the present research aims to complement the previous results using several techniques (i.e., spectral gamma-ray logs, x-ray diffraction analysis, sandstone petrography), to find further evidence of climatic change in the analyzed fluvial succession, or alternatively to test other forcing factors that could be relevant to understand the alluvial organization of the fluvial succession.

\section{Methodology}

\subsection{Outcrop spectral gamma-ray logs}

Three outcrop gamma-ray $\operatorname{logs}(\log \mathrm{X}, \log \mathrm{Y}$, and $\log \mathrm{Z}$ in Fig. 5) were obtained along the cliff face, through approximately $385 \mathrm{~m}$ of the Bajo Barreal Formation, with measurements using a vertical separation of $50 \mathrm{~cm}$. We adopted a counting time of 2 min during the fieldwork.
Weathering and local rubble coverage of the fine-grained sections led to the need for extensive trenching to achieve unweathered surface exposures. The natural radioactivity of the rock units was measured with a hand-held spectral gamma-ray scintillometer (Radiation Solutions model RS-125), which allows to show the result as the numerical value recorded by the spectroscope either as counts per minute over the determined sample time or as the content of radioactive elements in the sample ( $\%$ of $\mathrm{K}_{2} \mathrm{O}$ or ppm of $\mathrm{U}$ and $\mathrm{Th}$ ).

\section{2. $X$-ray diffraction analysis}

The mineralogical compositions and clay identification of eighteen mudstone samples were determined via $\mathrm{x}$-ray diffraction (XRD) analysis. Samples were collected from mudstones showing distinctive values in both Total GR and $\mathrm{K}$ values in the SGR logs, in order to find a link between $\mathrm{K}$ values in SGR log and clay types. Clays were separated using standard techniques, mounted in on glass slides and analyzed by x-ray diffraction including both air-dried and glycolate treatment. Clay minerals were identified according to Moore and Reynolds (1997), and I/S, mixed-layer clays after Srodon (1984). The following 001 peaks in the glycolate samples were used for identifying specific clays: smectite $17 \AA$, illite $10 \AA$, kaolinite $7.2 \AA$, chlorite $14 \AA$, and 4.26 for quartz; 001 peak height relative to the background was used as a relative indicator of the abundance of smectite. Kaolinite relative abundance compared to chlorite based on the $3.57 / 3.53 \AA$ peak heights ratio in glycolate samples (Chamley, 1989).

\subsection{Sandstone petrography}

Thirty-one sandstone samples from the Bajo Barreal Formation at Cerro Ballena exposures were collected from sedimentological logs $\mathrm{X}$ and Y. All samples represent the fine-to medium-grained, typically cross-stratified sandstones that are distinctive of channel fills in the Bajo Barreal Formation. The modal composition of the Cerro Ballena samples was analyzed by counting 500 points per thin section in a rectangular grid of $1 \mathrm{~mm}$ of spacing, following the Gazzi-Dickinson methodology (Ingersoll et al., 1984; Zuffa, 1985). The thin sections were impregnated with blue epoxy resin before thin section preparation 


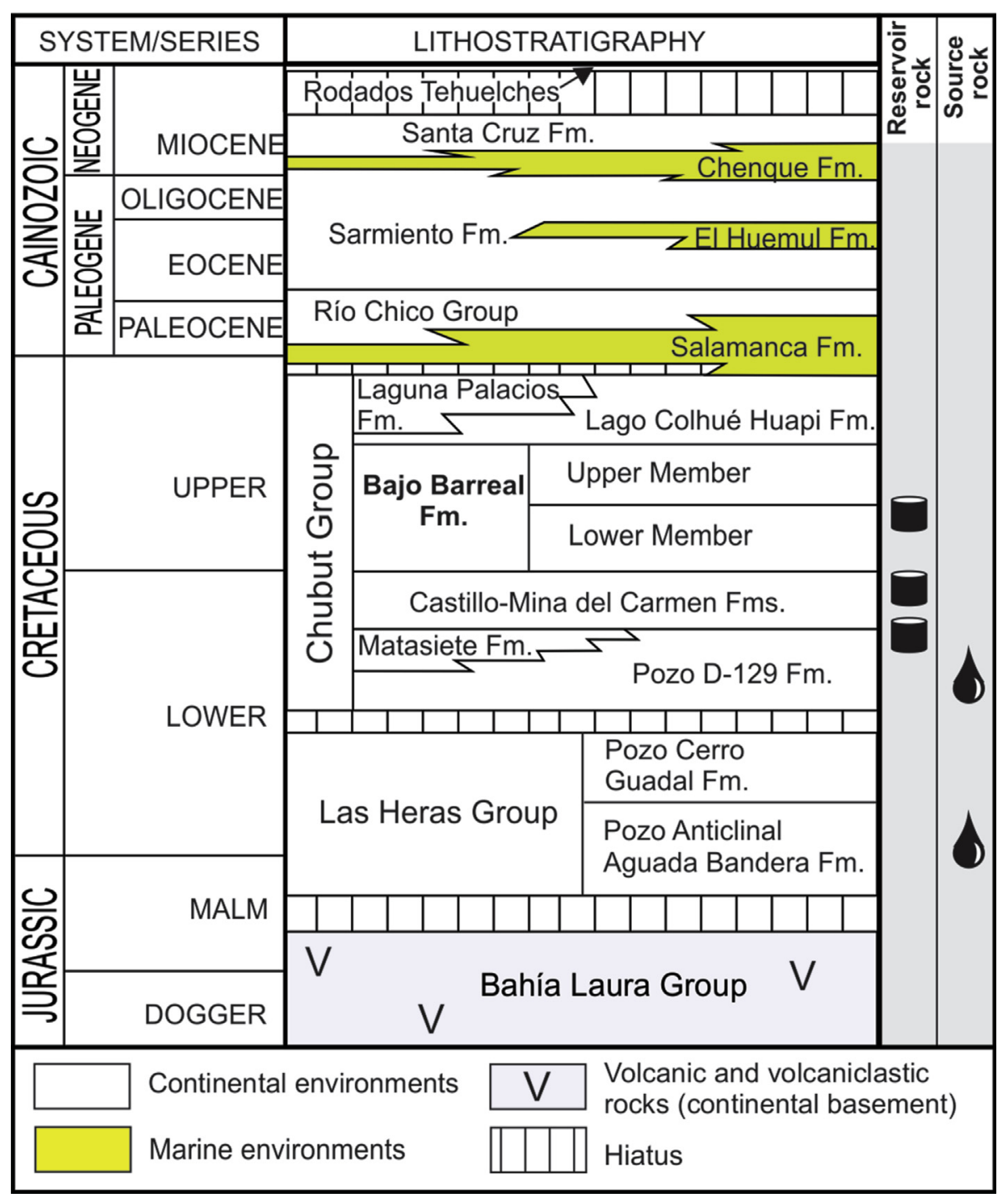

Fig. 2. Stratigraphic column of the Golfo San Jorge basin.

for the recognition of microscopy porosity. To discriminate dolomite from calcite, thin sections were stained with Alizarin Red-S (Dickson, 1966). Rounding and sphericity of grains were evaluated visually, based on the approach by Powers (1953).

\section{Outcrop spectral gamma-ray logs}

The three outcrop SGR logs from the Cerro Ballena anticline (location in Fig. 4) are shown in Figs. 6-8, together with the sedimentary $\log$.

\subsection{SGR counts, lithology and grain size trends}

SGR data from the Cerro Ballena anticline show moderately high radioactivity (dose rate: $45.6-180.0 \mathrm{nGy} / \mathrm{h}$; Total GR: $42.4-175.0 \mathrm{ppm}$ ) and concentration of $\mathrm{K}(0.4-3.4 \%), \mathrm{U}(0-17.6 \mathrm{ppm})$ and $\mathrm{Th}$ (4.1-22.1 ppm). The Total GR log is dominated by the potassium content shown by the high correlation (using the Pearson correlation coefficient $-r$ - as a measure of a linear relationship between variables) between potassium log and the total counts $(r=0.78)$ although $\mathrm{U}$ also shows high correlations with total counts $(r=0.75)$, and Th displays the less direct relation with total counts $(r=0.37)$. The generally weak correlation between elements (Th-K $r=0.20$; Th-U $r=0.17$; U-K $r=0.35$ ) suggests that the sum radioactivity is sourced from multiple mineral carriers. The control of the $\mathrm{K}$ content on Total GR values is also identified due to similar shapes of the K and Total GR logs for the whole sections, indicating that K-bearing minerals are responsible for the majority of the total gamma radiation from these rocks.

For our purposes, we grouped the SGR data according to the described lithology and grain size in seven main facies categories, as follow: LITH1: Conglomerates, LITH2: Sandstones, LITH3: Siliciclastic siltstones, LITH4: Siliciclastic mudstones, LITH5: Fine-grained tuffs, LITH 6: Tuffaceous siltstones, LITH 7: Coarse-grained lahar deposits. A correlation matrix for Total GR and the three radioactive components is shown for the overall data, and for the seven selected facies categories (Fig. 9A). A statistical summary of the collected gamma-ray data, arranged by lithology/grain size, and stratigraphic interval (Section) is shown in Fig. 9B.

Th measurements show increasing values from conglomerates to mudstones, although the statistical overlapping is important, whereas $\mathrm{U}$ values show decreasing record from conglomerates to mudstones, although the $\mathrm{U}$ trend is less defined than for Th element. Moreover, the distinctive marker bed that separated Sections A and B (identified as LITH 7) shows very low values of $K$ and total GR.

In conglomerates and sandstones, $\mathrm{U}$ and Total GR show high correlations (sandstones $r=0.83$; conglomerates $r=0.90$ ), evidencing that the main contributor to the total radioactivity is the $\mathrm{U}$ element. High-radioactivity in conglomerates and sandstones is generally 

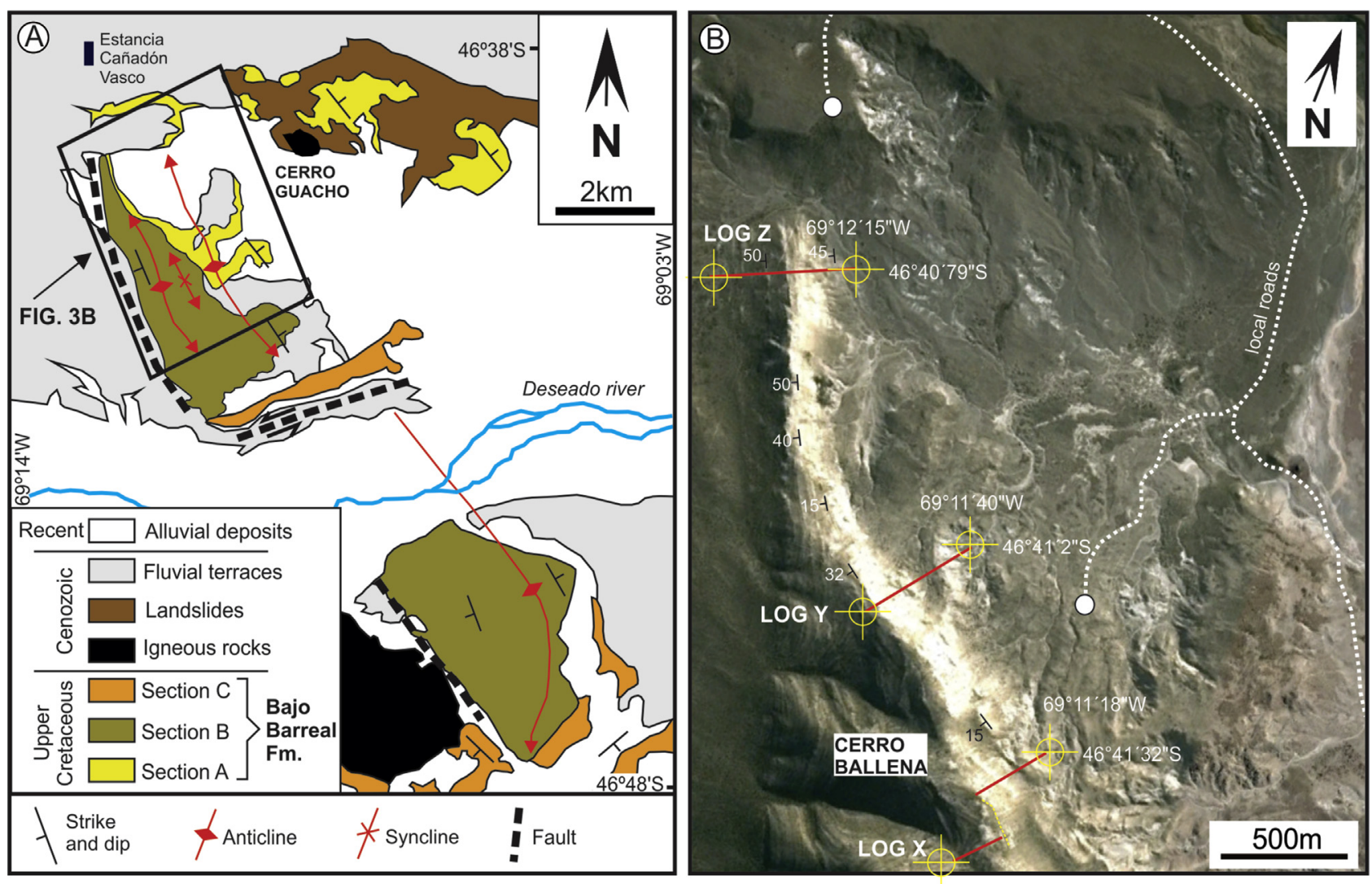

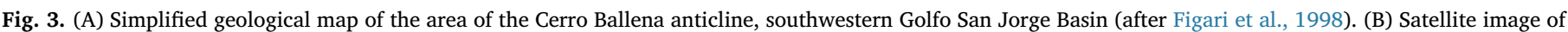

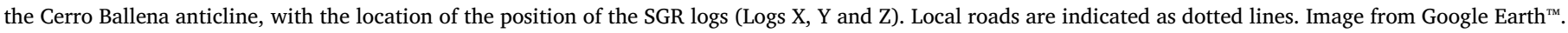

attributed to the contents of mica, K-feldspars, lithic fragments, and heavy minerals (Rider, 1999). However, in our study area, high values of $\mathrm{U}$ in conglomerates and sandstones are probably associated either with diagenesis or with fluid migration and not with the occurrence of heavy minerals in the fine-grained matrix, due to the characteristic oil staining of the matrix of coarse-grained facies, observed during the fieldwork. Although some trends can be identified using the concentration of $\mathrm{U}$ in sandstones and the Th distribution evidence some relation with grain size (Fig. 9B), the considerable overlap of values and small differences between facies categories do not allow to make lithological distinction using solely basic statistics.

\subsection{SGR correlations and $\log$ motifs}

The lateral correlation of the outcrop SGR logs (Fig. 10) use as a datum the distinctive volcaniclastic marker bed showed in Fig. 5. Paredes et al. (2018a) divided Section A into several major zones of tens of meters according to its sandstone content (indicated as M1, S1, M2, S2, and M3 in ascending order). The major subdivisions of Section A can be traced confidently between the outcrop SGR logs with minimum thickness variations, evidencing a layer-cake distribution of the main packages. Moreover, we correlate outcrop SGR data with Well V and Well W of the Cerro Wenceslao oilfield using two distinctive log motifs identified within Section A. In the lowermost part of the fine-grained succession of Section A, a upward reduction of GR values in subdivision M1-B can be compared with an equivalent GR motif identified in Well W. A second distinctive GR motif occurs in the S2 subdivision (Fig. 10), associated with an upward reduction in both GR and $\mathrm{K}$ values.

The three sedimentological logs in Section $\mathrm{B}$ contain a larger "sand:mud" ratio $(\log X=0.45 ; \log Y=0.38 ; \log Z=0.31$, as measured in the vertical sections). The higher sandstone content produces a more irregular motif in U and Total GR logs in Section B, revealing an intricate pattern that makes it challenging to attempt lithological predictions or grain-size trends using SGR data alone.

\section{Clay mineralogy and SGR record}

We select ten mudstone samples for analysis by $\mathrm{x}$-ray diffraction from Section A, and eight additional samples were collected from Section B. As mentioned, the sampling procedure was guided by observed trends in both Total GR and K values in the outcrop SGR logs, testing a possible link between $\mathrm{K}$ values in SGR log and clay minerals.

\subsection{Trends in clay composition within section $A$}

In fine-grained samples from Section A in Log Z (Fig. 11), the wholerock composition is dominated by quartz (about 32-60\%) and clay minerals (37-65\%), with minor amounts of $\mathrm{K}$ feldspar (traces to $1 \%$ ), plagioclases (1-3\%), and calcite in three samples (traces to $2 \%$ ). The main clay minerals in all ten samples are smectite (45-79\%), kaolinite (1-55\%), and a single sample contains mixed-layer illite-smectite (99\%). X-ray diffraction data indicate that although feldspars are present, clay minerals are volumetrically the most important source of $\mathrm{K}_{2} \mathrm{O}$, suggesting that clay mineral distribution and type will be the primary control on $\mathrm{K}_{2} \mathrm{O}$ distribution in the $\mathrm{K}$ log. Samples from the basal levels of S2 stratigraphic interval are dominated by smectite, whereas clay minerals gradually change upward from smectite to kaolinite through S3, and parallel the gradual and systematic upward reduction in both the GR and $\mathrm{K}$ content.

\subsection{Trend in clay composition within section $B$}

With increasing sandstone content within Section $B$, we recognize an extra level of heterogeneity associated with the $\mathrm{U}$ enrichment in 

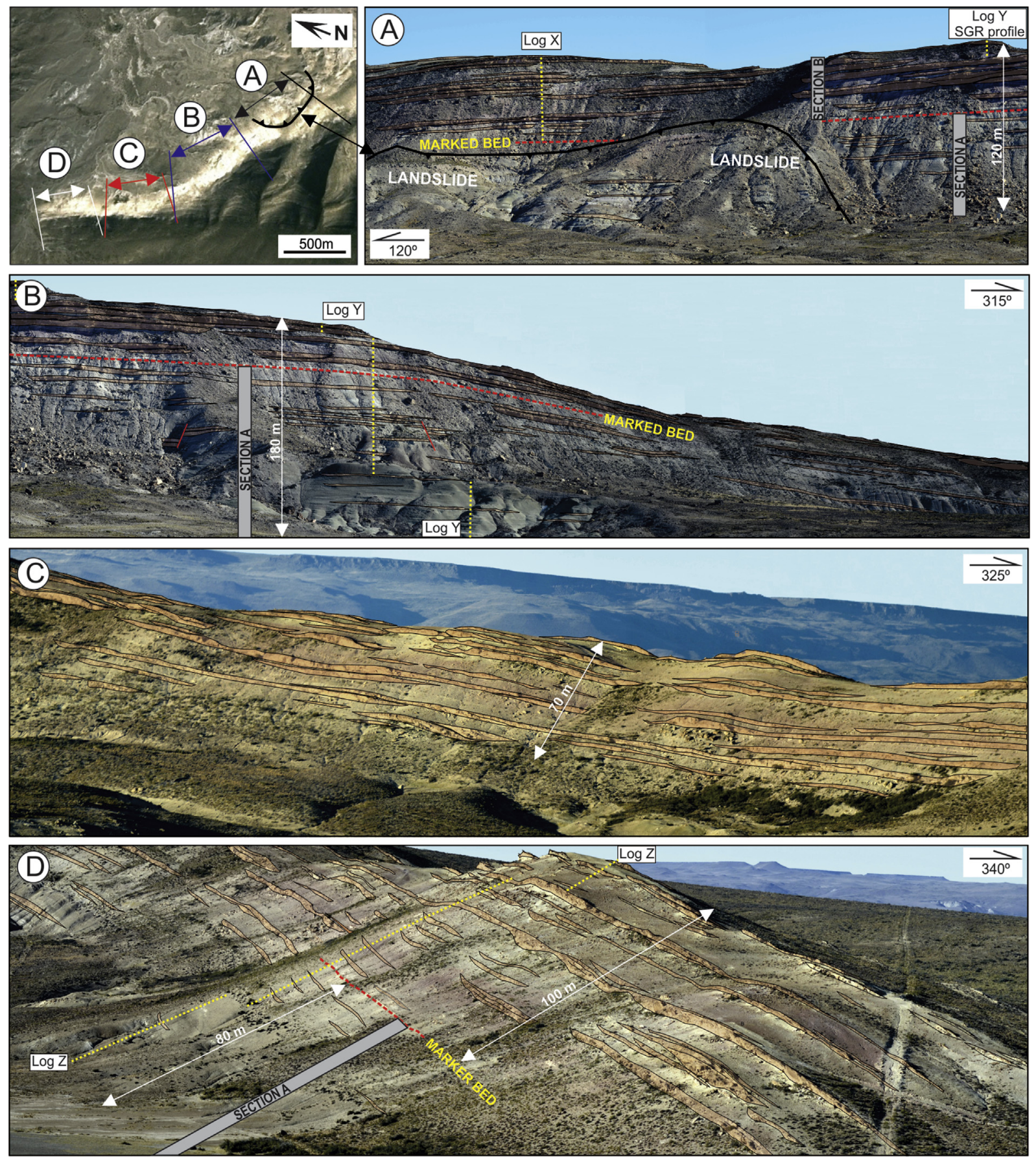

Fig. 4. Field appearance and interpreted channel bodies over gigapans of the Bajo Barreal Formation in the Cerro Ballena anticline. Pale brown polygons outline interpreted channel belts, whereas a distinctive marker bed that separates Section A of the overlying Section B is indicated as a red, dotted line. The location and an approximate trace of the three outcrop SGR logs are indicated. (For interpretation of the references to color in this figure legend, the reader is referred to the Web version of this article.)

porous media (Osmond and Ivanovich, 1992), favoring the general lack of predictable GR trends in this stratigraphic interval, and making correlation from GR log pattern very difficult. We collected eight samples from a $25 \mathrm{~m}$ thick section within Section B in Log Z (location in Fig. 8) in order to test genetic relationships between GR-SGR values and clay minerals, after identifying a log trend of increasing, and then decreasing values in both Total GR and $\mathrm{K}$ logs (Fig. 12). Thus, we analyze the samples in the likelihood that they contained a systematic variation in clay content regarding the measured Total GR and K content. Wholerock composition of the samples show elevated quartz content (range 48-80\%) and clay minerals (19-49\%), with subordinate amounts of $\mathrm{K}$ feldspar (traces to $2 \%$ ), plagioclases in two samples (2-5\%), calcite in three samples (traces to $12 \%$ ), and ankerite (4\%) and hematite (1\%) in a single sample. The main clay minerals are represented by kaolinite in all samples (34-98\%), smectite in three samples (18-66\%), minor content of illite in six samples (1-8\%), and a single sample contain mixed-layer illite-smectite (10\%). Crystallinity is good in kaolinite, good to regular in illite, regular to poor in smectite, and poor in I/S samples. Moreover, samples showing high kaolinite content (e.g., samples CB-11 and CB-18) record the lowermost Total GR values and K content within the sampled interval. Those samples containing smectite show intermediate to high SGR counts, whereas the illite content, to a 


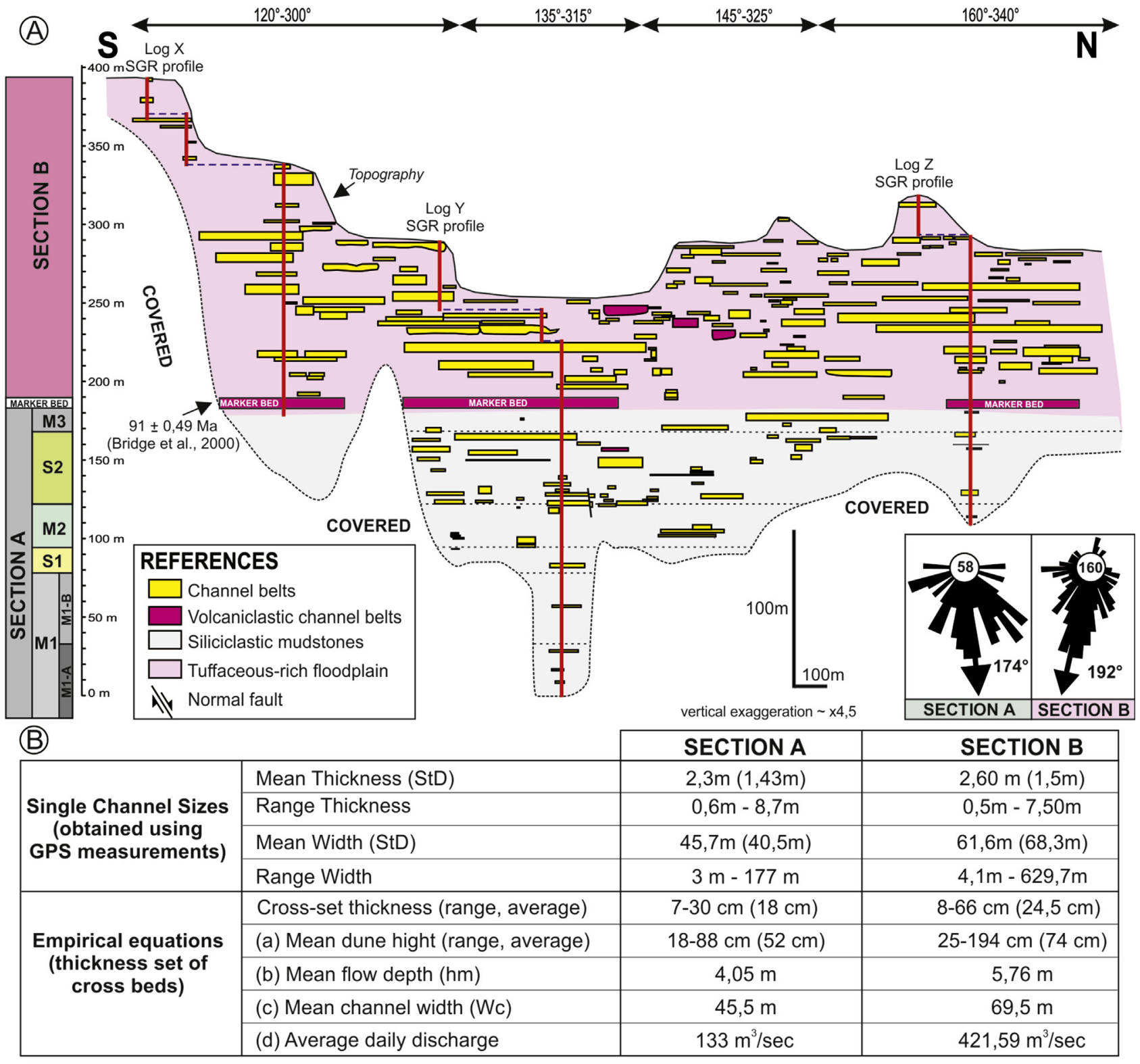

(a) $\mathrm{hm}=5,3 \beta+0,001 \beta^{2}, \beta \equiv \mathrm{Sm} / 1,8, \mathrm{Sm}=$ mean cross-set, $\mathrm{hm}=$ mean dune height (Leclair and Bridge, 2001; Leclair, 2002).

(b) $6<\mathrm{d} / \mathrm{hm}<10$ (d=mean flow depth) (Bridge and Tye, 2000).

(c) $\mathrm{Wc}=8,88 \mathrm{dm}^{1,82}, \mathrm{dm}=0.5 \mathrm{~d}$ (Bridge and Mackey, 1993).

(d) $Q=$ Area.v; ( $v=$ velocity neccesary for dune migration, a $v=0,75 \mathrm{~m} / \mathrm{sec}$ is assumed)

Fig. 5. (A) Panel showing mapped stratigraphy and facies architecture in the Bajo Barreal Formation along the western flank of the Cerro Ballena anticline, with the position of the measured spectral gamma-ray logs X, Y, and Z. Average paleoflow data and subdivisions of Section A are indicated (modified of Paredes et al., 2018a). (B) Summary of measurements of single-channel sizes and paleohydrological estimations derived from measurements of thickness set of dune-scale cross-beds in single-channel fills. We obtained the width of single channels using GPS data on 58 channels of Section A, and on 160 channels of Section B. Cross-set thickness data were obtained from 11 channels of Section A, and on 30 channels of Section B (after Paredes et al., 2018a).

certain extent, shows direct correspondence with the count in $\mathrm{K}$ (e.g., from samples CB-11 to CB-13).

\section{Detrital sandstone composition}

Point-count results were tabulated and recalculated, and the entire dataset is shown in the Supplementary Material. A general description of the detrital constituents is provided next, after Olazábal et al. (2019).

Detrital quartz is generally sub-rounded to sub-angular with variable grain size ranging between coarse-to fine-grained. Grains are predominantly monocrystalline, with embayed volcanic and fluid inclusions. Polycrystalline quartz is present in low proportion, displaying mainly straight to curved sutured contacts between individual crystals, with more than three sub-grains displaying preferred crystallographic fabric, probably of metamorphic origin.

K-feldspars are in all samples more abundant than plagioclase. Distinctive orthoclase and sanidine grains are present in most samples, whereas the plagioclase composition varies from oligoclase to andesine. Both components are altered and corroded and partially dissolved.

Volcanic rock fragments are abundant. Basic and intermediate volcanic rocks were identified based on lathwork and microlithic textures (Ingersoll and Cavazza, 1991), whereas the occurrence of porphyritic and felsitic textures suggests acidic lava flows as the likely source. Lithic fragments with vitreous and eutaxitic textures are indicative of a 


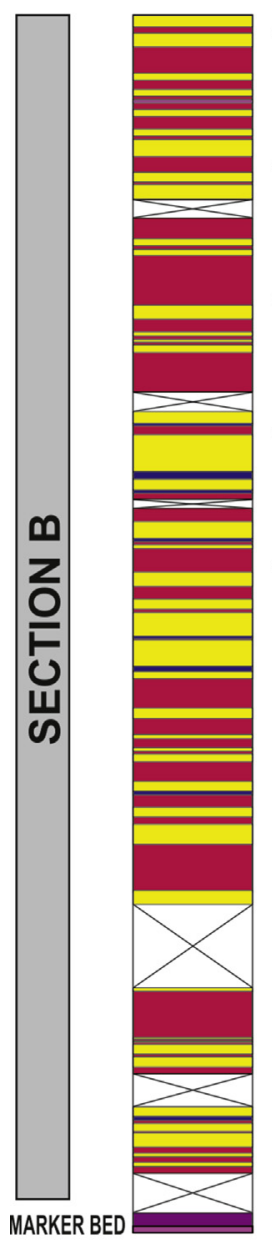

Lithology

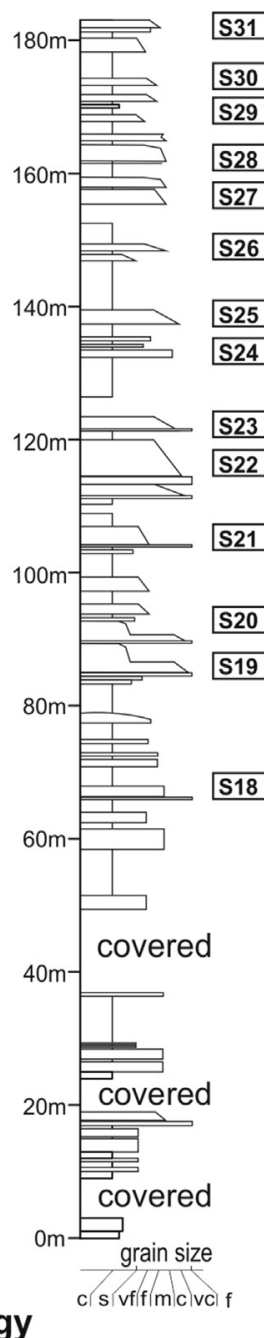

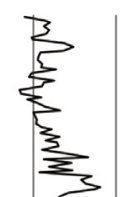
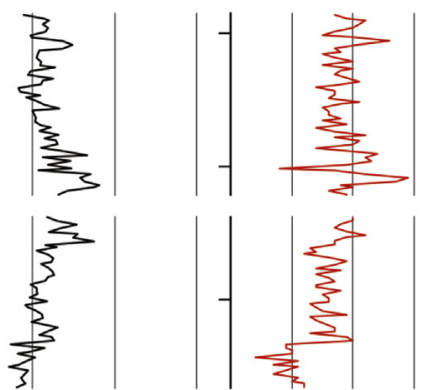

$\sum_{5}^{\xi}$<smiles>C1CC2CC1C2</smiles>
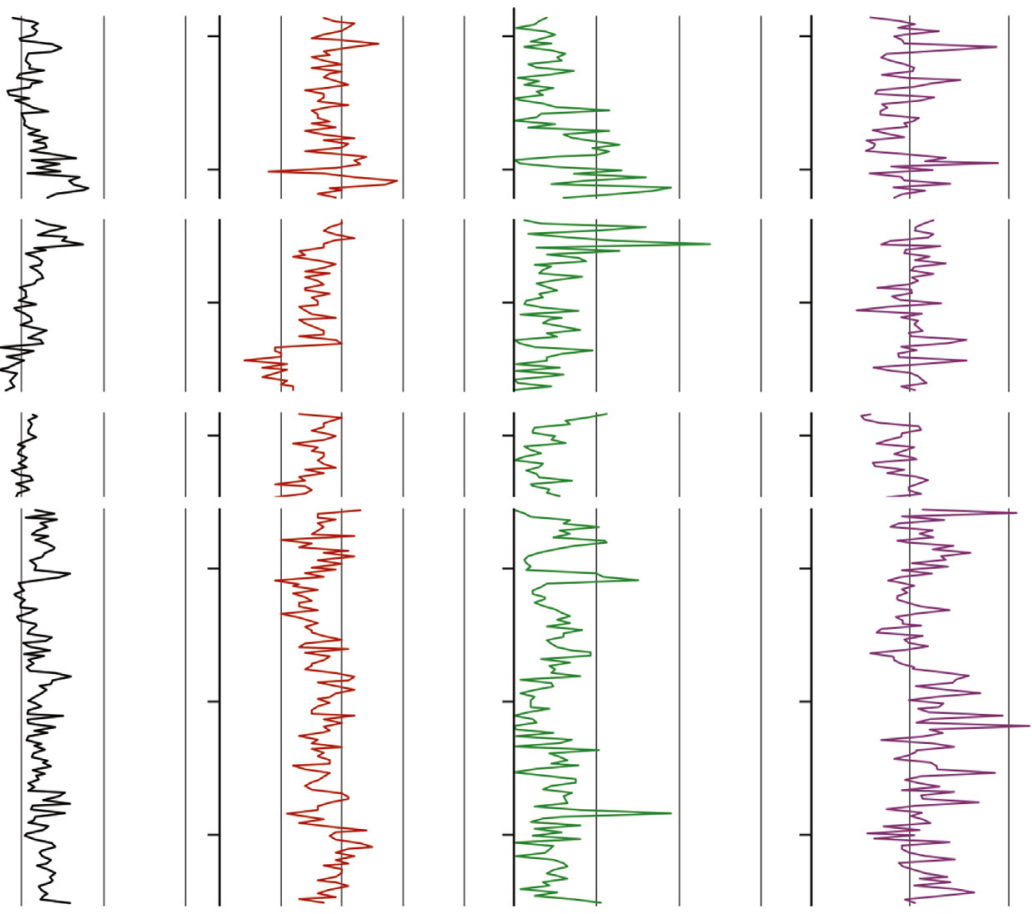
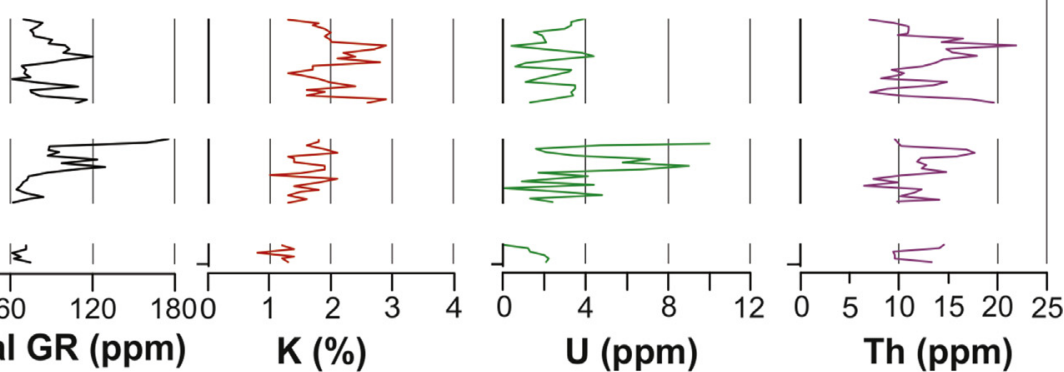

\section{KEY OF LITHOLOGIES}

$\square$ LITH 1: Fine conglomerates

$\square$ LITH 2: Coarse to fine-grained sandstones

$\square$ LITH 3: Siliciclastic siltstones

$\square$ LITH 4: Siliciclastic mudstones
QLITH 5: Fine tuffs

$\square$ LITH 6: Tuffaceous siltstones

$\square$ LITH 7: Coarse-grained lahar (marker bed) $n$ Samples for petrographical studies

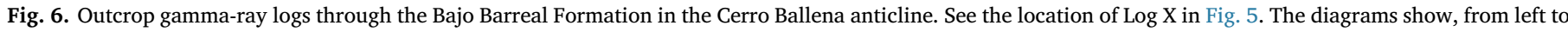

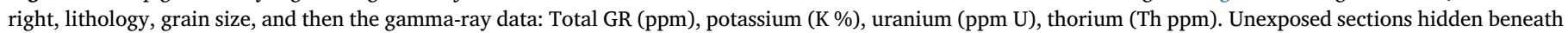
talus, where SGR data could not be collected, are shown as gaps.

pyroclastic source, and the occurrence of pumice components and glass shards reflects coeval, acidic volcanic activity (Umazano et al., 2009; Tunik et al., 2015). Metamorphic rock fragments are rare, where present they are of high-medium metamorphic rank (Garzanti and Vezzoli, 2003).

The proportion of matrix is generally low (less than 2\%), consisting of interstitial clay minerals and pseudomatrix (Dickinson, 1970; Dunn, 1992). Biotite, muscovite, zircon, and heavy minerals are minor constituents of all sandstones. The most abundant types of cement are carbonates (calcite, dawsonite, and dolomite), whereas clay coatings are common, with the limited occurrence of iron oxide cement. Several samples of Section B and the marker bed show dawsonite, as a pervasive alteration of detrital components.

The porosity evaluated on thin sections occurs as both secondary and altered primary types. Most of the secondary porosity form moldic pores, but dissolution pores were formed as a result of both dissolution of framework grains and calcite cement, and fracture pores are locally found.

According to Folk et al. (1970), the analyzed sandstones from Section A (Fig. 13B) correspond to feldspathic litharenites $(n=7)$, litharenites $(n=1)$ and feldarenites $(n=1)$ with modal averages $Q_{20} F_{33} L_{47}$ and $\mathrm{Lm}_{1} \mathrm{Lv}_{99} \mathrm{Ls}_{0}$. Sandstones from Section A are mineralogically and texturally immature, with an average of $32 \%$ of intergranular material (matrix and cement) and 56\% of detrital components. The lithic fraction (Fig. 13A) mainly consist of lithic clasts of acidic volcanic rocks (average abundance of $19 \%$ ), pyroclastic fragments (46\%) and highly altered pyroclastic fragments $(18 \%)$; all the samples contain intermediate to basic volcanic fragments (14\%), whereas fragments of metamorphic and plutonic origin are uncommon (2\%) and sedimentary fragments are scarce $(\ll 1 \%)$. 


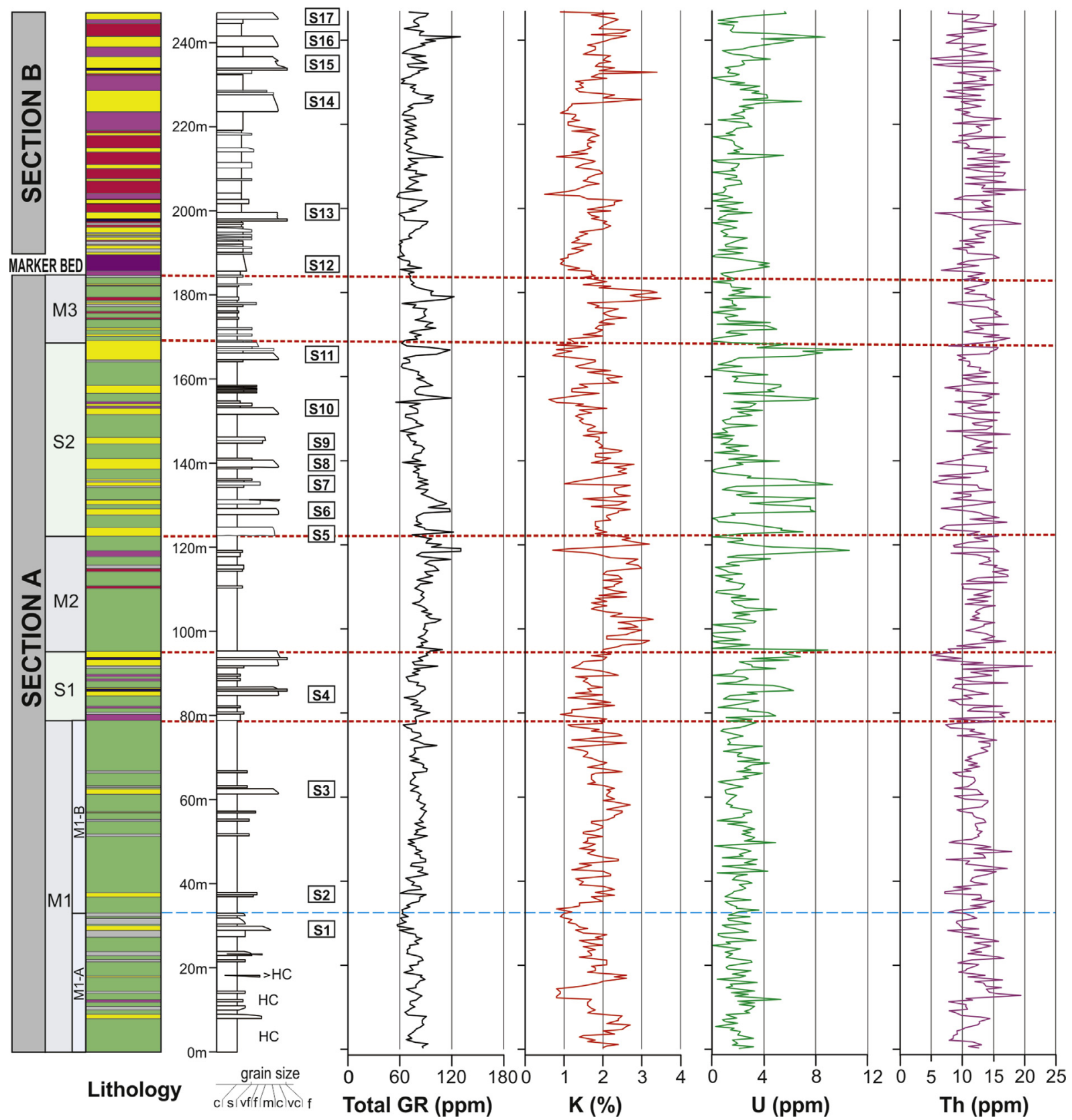

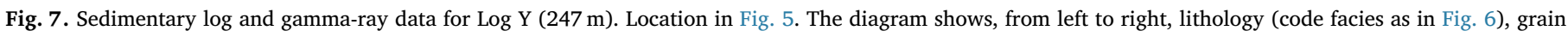

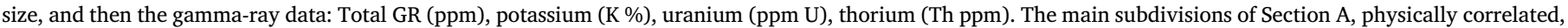
and walked out along the exposures, are indicated using operational markers.

In contrast, samples from Section $B(n=18)$ correspond entirely to litharenites with modal averages of $\mathrm{Q}_{31} \mathrm{~F}_{7} \mathrm{~L}_{62}$ and $\mathrm{Lm}_{1} \mathrm{Lv}_{99} \mathrm{Ls}_{1}$. The detrital framework, on average, represents $40 \%$, whereas intergranular components are up to $48 \%$. The lithic fraction consists of pyroclastic fragments (53\%), acidic volcanic rocks (average abundance of $22 \%$ ) and highly altered pyroclastic fragments $(23 \%)$, whereas fragments of metamorphic and plutonic origin are uncommon (2\%) and sedimentary fragments are scarce $(\ll 1 \%)$. Samples from Section B show a significative reduction in $\mathrm{K}$ content $(7 \%$ average), whereas basic-intermediate components are below 3\% in seven samples (Fig. 13A).

Interpretation: Data indicate that sandstone samples from Section A and Section B correspond to different petrofacies (Ingersoll, 1978) and can be compared with previous petrographical results of the Bajo Barreal Formation. Ibañez et al. (2015) identified feldspar litharenites and litharenites from samples along exposures of the Bajo Barreal
Formation in the Cerro Guadal oilfield, located $26 \mathrm{~km}$ toward NNW; their data overlap the field of compositions in the QFL diagram (Folk et al., 1970) of samples obtained in Section A of the Cerro Ballena. Limarino and Giordano (2016) analyzed arenites from subsurface samples of the Bajo Barreal Formation with comparable detrital components to those recognized in Section A, identifying two distinctive petrofacies, referred as VF and VP. Limarino and Giordano (2016) consider both petrofacies as indicative of provenance from volcanic terrains, discriminating VF and VP petrofacies by the relative proportion of plagioclase and k-feldspar within the sandstones. The VP petrofacies contain a percentage of plagioclase twice that of k-content and are considered related to source areas located in the Deseado Region, whereas in the VF petrofacies the K-content is similar to the plagioclase percentage, being sourced from the Andes Cordillera (Limarino and Giordano, 2016). Sandstone samples of Section A do not fix with the 


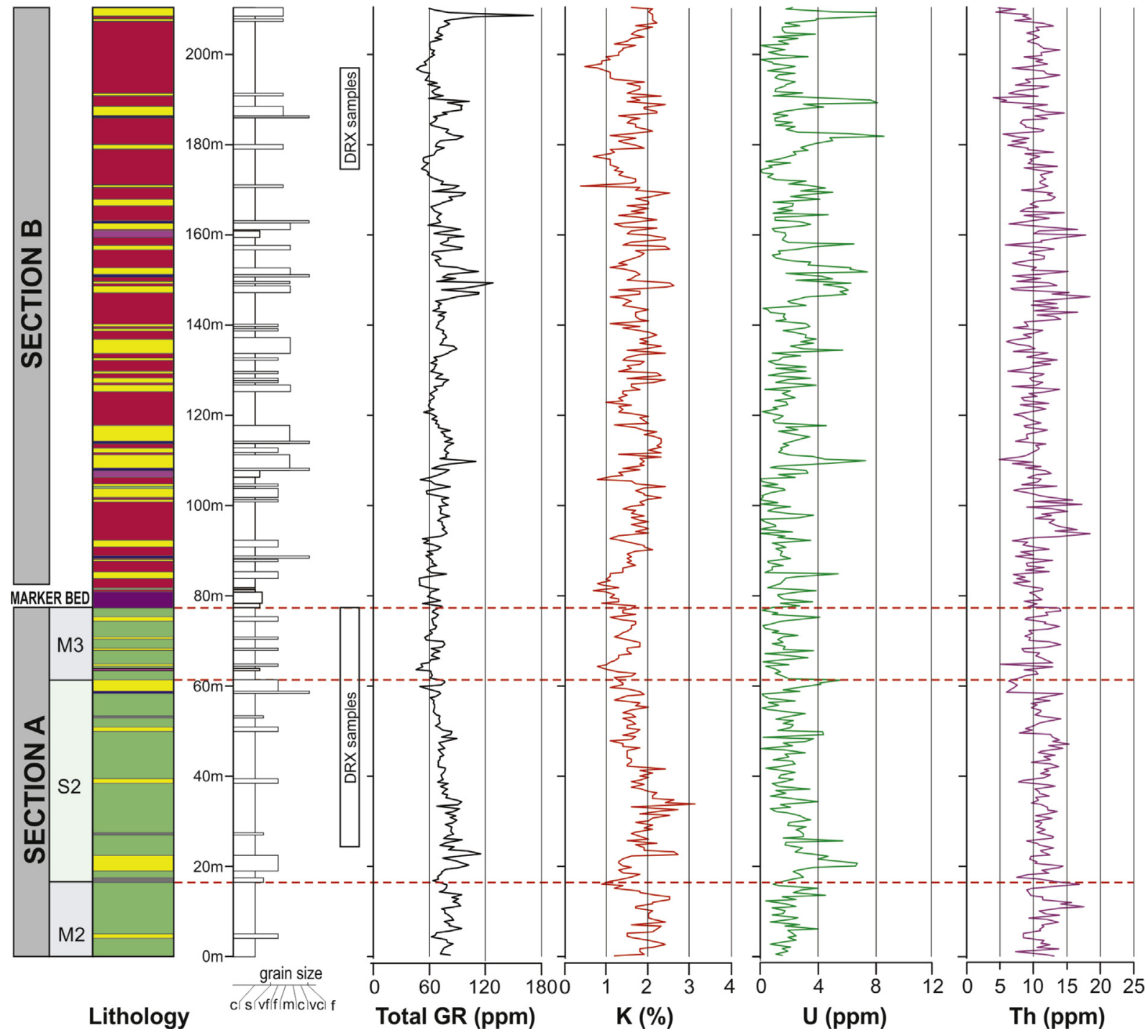

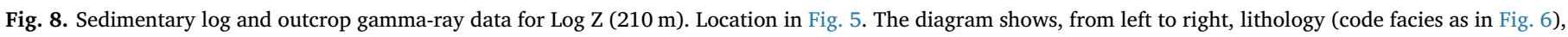

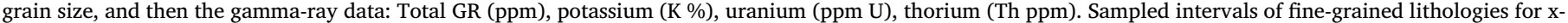
ray diffraction studies are marked right to the sedimentological log.

previous characterization of petrofacies VP and VF, because they contain a more substantial proportion of basic-intermediate components, and plagioclase percentages are similar to k-feldspar content. Thus, we consider that the detrital composition of sandstone samples from Section A reflects a mixture of components, with dominant acidic components derived from the Andes Cordillera, and contribution from basic-intermediate volcanic-volcaniclastic rocks derived from the underlying Bajo Pobre Formation of the Bahía Laura Group (Clavijo, 1986; Panza and Haller, 2002; Cobos and Panza, 2003), outcropped few kilometers southward of the study area. All samples from Section B corresponds to petrofacies VF of Limarino and Giordano (2016), and thus they are linked to a source area dominated by acidic volcanic rocks derived from the Andes Cordillera.

\section{Discussion}

The evolution of the Bajo Barreal Formation is discussed here with particular attention to the links between stacking styles, the trends in spectral gamma-ray log and clay composition as well as depositional controls.

\subsection{Origin of trends in SGR logs and clay minerals}

Section A. The upward reduction in K and total GR through S-2 and S-3 sub-units of Section A can be linked to the observed clay minerals. Higher potassium values in basal levels of S2 sub-unit is probably a result of the substitution of $\mathrm{K}$ in the structure of smectites before undergoing diagenesis (Drief and Nieto, 2000). The upward increase in $\mathrm{Al}_{2} \mathrm{O}_{3}$-enriched kaolinite through Section A (Fig. 11) constitutes the likely reason for lower radiation values in both Total GR and $\mathrm{K}$ logs in mudstone samples, probably reinforced by leaching from feldspars during kaolinite formation (Parkinson, 1996).

Limarino et al. (2017) analyzed the diagenetic evolution of subsurface sandstone samples of the Bajo Barreal Formation at depths ranging from $\sim 500 \mathrm{~m}$ to up to $2500 \mathrm{~m}$, identifying a complex evolutive history with seven diagenetic stages. Although clay transformations during the burial of the studied succession cannot be ruled out, the Cerro Ballena is located very close to the southern basin boundary and has been covered by limited (if any) Cenozoic strata, with Cenozoic uplifting linked to the building of the San Bernardo Fold Belt. Consequently, we consider that the succession has not undergone significative burial, probably less than $500 \mathrm{~m}$, and clay mineral variations are attributed to changes in the chemical weathering rate in the early 


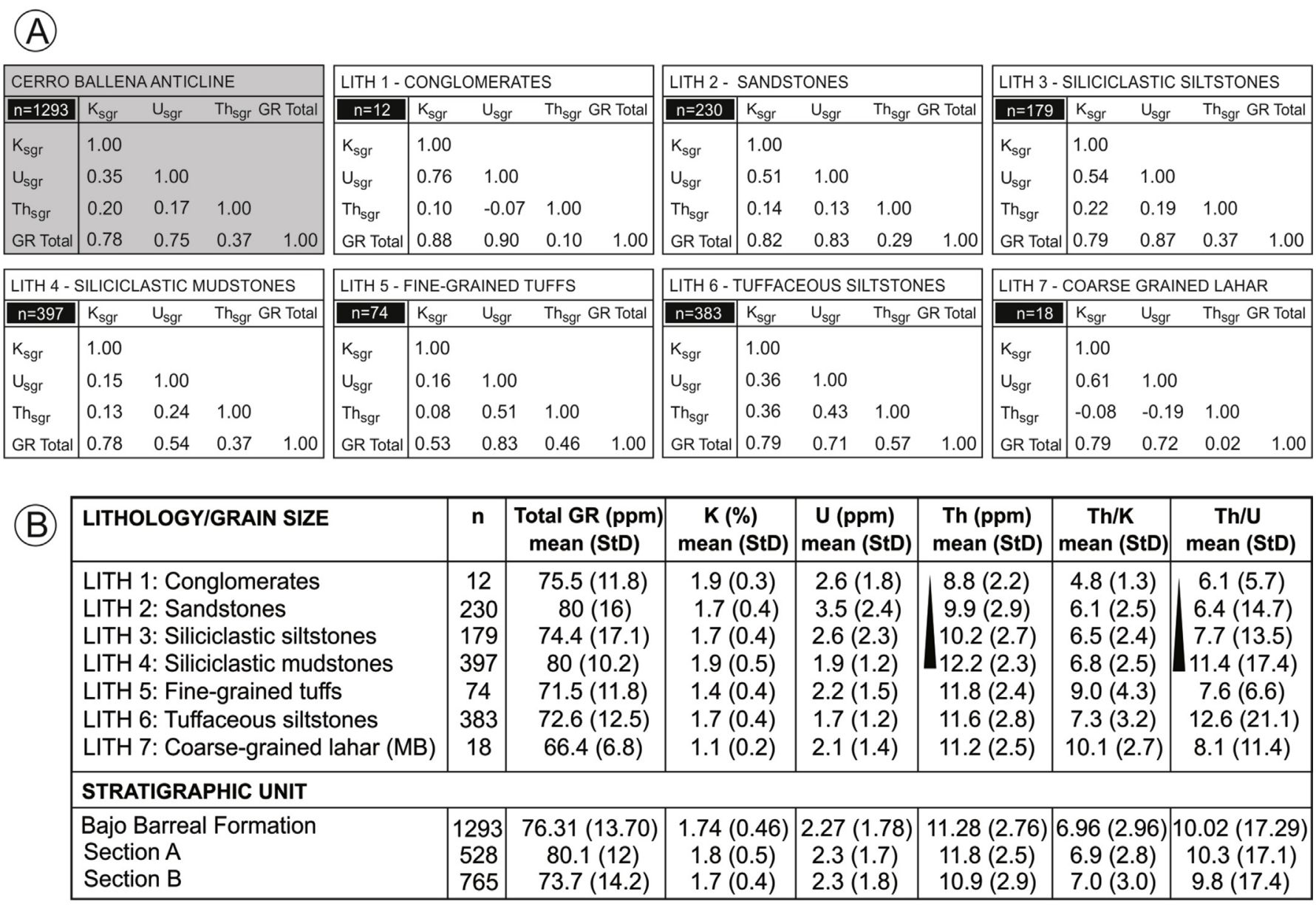

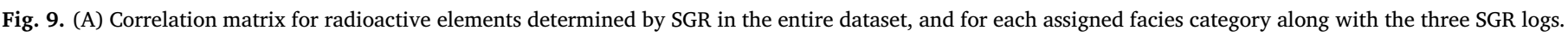

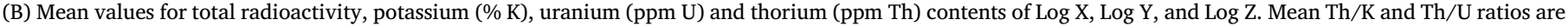
also indicated. StD, standard deviation.

\section{diagenesis.}

We thus consider that the upward K reduction throughout Section A identified in SGR logs and the corresponding increase in kaolinite values are associated with the increase of paleo-weathering in humid conditions, while the low total GR counts values toward the top of Section A are associated with both enhanced continental leaching and changes in clay type. Several studies (Senkayi et al., 1987; Thiry, 2000; Sáez et al., 2003; Worden and Morad, 2003; among others) pointed out that kaolinite can result from the alteration of volcanic-volcaniclastic components under warm and humid climatic conditions, whereas smectite can be formed from the alteration of volcanic or volcaniclastic material or a variety of authigenic processes and climatic conditions (Chamley, 1989; McKinley et al., 2003; Galán, 2006). The single sample containing I/S mixed layer may results from moderate chemical weathering under surficial conditions (Chamley, 1989), and can occur during the transformation of smectite under seasonal climates due to pedogenetic processes (Wilson, 1999; Raucsik and Varga, 2008) or from altered volcanic materials (Lindgreen and Surlyk, 2000; Shoval, 2004).

Section $B$. Increasing, and then decreasing GR counts and $\mathrm{K}$ content in the sampled stratigraphic interval of Section B show close correspondence with the variations in the kaolinite-smectite ratio (Fig. 12). Our results suggest that reading of Total GR and K counts can be linked with vertical changes in clay minerals within the study succession in accordance with previous studies that related abundance of clay minerals in sedimentary rocks to the ratios of $\mathrm{K}$, Th and $\mathrm{U}$ (Myers and Bristow, 1989; Slatt et al., 1992; Ruffell and Worden, 2000). However, the small number of XRD measurements in Section B prevents more detailed statistical correlations between clay content and SGR values.
The results indicate an overall higher kaolinite content that samples collected in Section A, supporting the inferences of higher weathering rate toward upper levels of the analyzed succession (Millot, 1970; Weaver, 1989). Besides, to date, no paleosol studies have been carried out in the Cerro Ballena. Although during the fieldwork we do not find evidence of either mature paleosols or distinctive soil horizons, more research on the paleosols of the Bajo Barreal Formation in this area is needed to evaluate subtle changes in soil-forming processes and mineralogy. Probably, future research in micromorphological and geochemical characteristics of poorly-evolved paleosols can improve our understanding of the analyzed fluvial strata.

\subsection{Origin of changes in detrital provenance}

The vertical compositional trend observed within the sandstone samples reveals a precise change in detrital modes at the boundary between Section A and Section B. Particularly, we noted a noticeable upward reduction in both potassium content and basic-intermediate igneous components (see Fig. 13), and the increase in unstable, acidic volcanic components, demonstrating changes in bedload composition in the rivers of Section B. These changes occur synchronously to the observed change in floodplain composition from epiclastic-derived, grey-colored mudstones and siltstones of Section A to red-colored, tuffaceous siltstones in Section B, and parallel the increase in channel proportion (Figari et al., 1998). Floodplain construction within the Bajo Barreal Formation has been associated with reworking by the water of epiclastic and volcaniclastic components during floods (Umazano et al., 2008), while only a minor proportion of ash-size beds are related to 


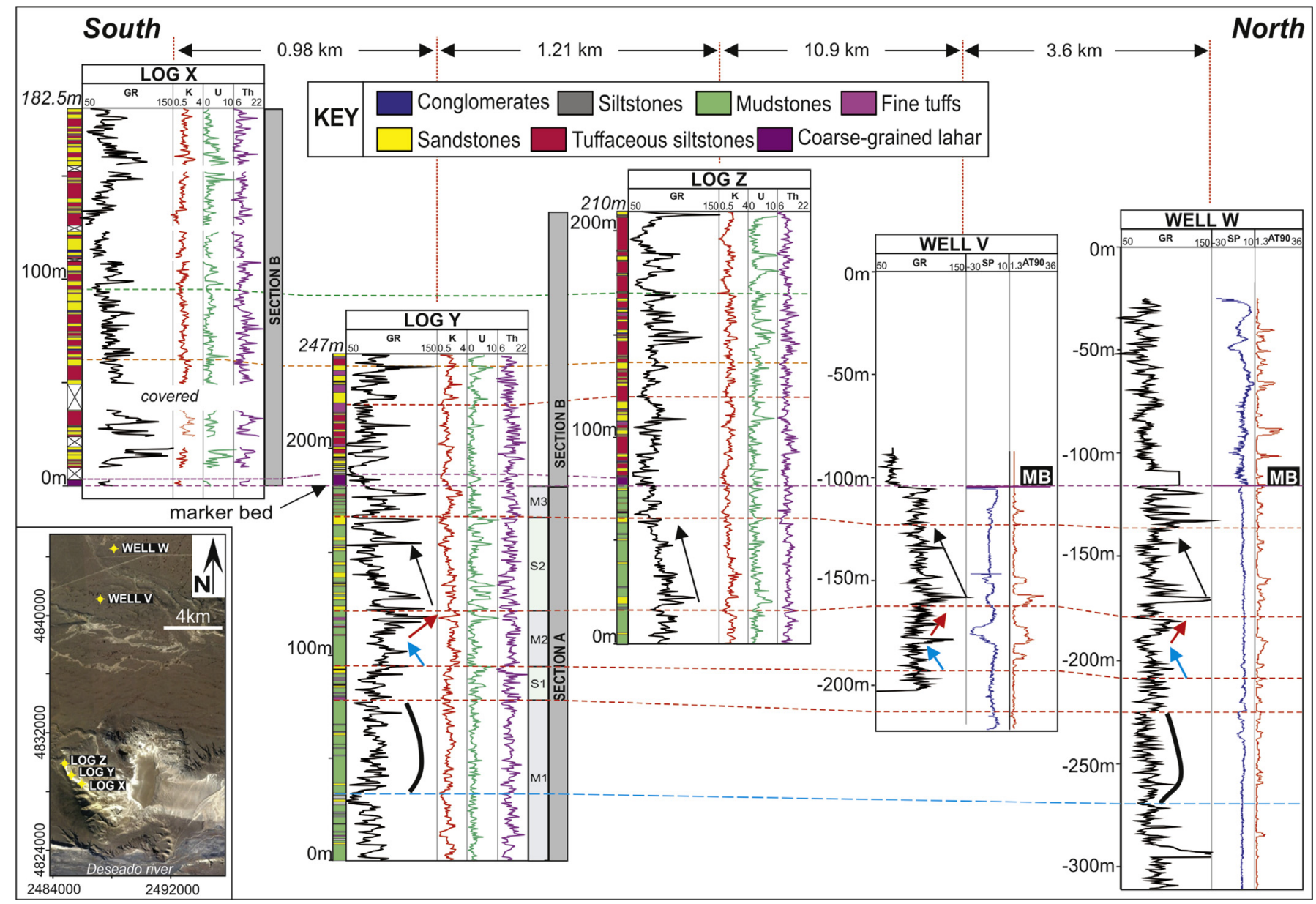

Fig. 10. SGR-log stratigraphic correlation between outcrop gamma-ray logs obtained in the Cerro Ballena anticline (Logs X, Y, and Z) and wells V and W of the Cerro Wenceslao oilfield. The horizontal datum corresponds to the tuffaceous marker bed (MB) located at the base of Section B. The described lithologies are indicated to the left of the GR logs. Major sub-divisions and distinctive log patterns observed in Section A and B are also represented. An upward decrease in Total GR and K counts can be observed throughout S2 and M3 packages of Section A, which can be confidently identified in the subsurface. See the inset map for location. Key: $\mathrm{SP}=$ spontaneous potential, AT90 = deep resistivity.

direct airfall derived from distal volcanic activity (Paredes et al., 2016). As detrital composition changes occur as a result of erosion and unroofing, in a conformable succession, such changes in composition are gradual and continuous (Graham et al., 1986). On the contrary, significant breaks in sedimentation can be identified by sudden changes in clast composition across an erosion surface (Colombo, 1994; Miall and Arush, 2001), and are useful to define sequence boundaries.

From the above considerations, several likely explanations emerge concerning the observed changes in the detrital modes. Synchronous changes both in bedload mineralogy and in suspended-load types should require a significant reorganization in the drainage network toward the hinterlands, which would lead to the incorporation of a considerable amount of unstable, volcaniclastic-derived components in the flanks of the Andes Cordillera. Alternatively, stream piracy of a larger-scale catchment in a closer position to the study site could also be effective in producing sudden mineralogical changes, providing instantaneously large volumes of pyroclastic-acidic components, with the dilution of the basic-intermediate components. Besides, it is also possible that coeval changes in detrital provenance, suspended-load components, and the scale of the channels could have been triggered by a sudden reorganization of the channel network linked to increased volumes of water being transferred within the catchment in more humid conditions. These impacts could be even reinforced due to the relative low permeability of tephra components that built up the floodplains of Section B in relation to epiclastic components of floodplains in Section
A, reducing the infiltration capacity of the floodplain and favouring runoff increases during floods or heavy rains (e.g., Swanson et al., 1982; Smith, 1991). In this scenario, the increase in both water and sediment supply within the channel network in a relatively flat geomorphic scenario can, in turn, led to either increasing frequency of channel avulsion (Bryant et al., 1995) or increasing migration rates (Leeder, 1978; Mack and Leeder, 1998) favoring greater interconnectivity among channel deposits.

\subsection{Negligible influence of local tectonics or base level on stacking and connectivity}

In alluvial settings, the recognition of depositional sequences relies on the identification and correlation of subaerial unconformities and contrasting stacking patterns. Classical models of fluvial depositional sequences define three systems tracts similar to that observed in marine environments (Legarreta et al., 1993; Wright and Marriott, 1993; Shanley and McCabe, 1994), but other studies proposed a model of fluvial depositional sequences composed of only two systems tracts (Martinsen et al., 1999; Catuneanu, 2006). In the two-stage scenario, contrasting stacking pattern allows defining high- and low-accommodation systems tracts in fluvial sequence stratigraphy, defined by variations in the overbank/fluvial channel ratio (Martinsen et al., 1999) and by variations in the geometry of the involved channel belts (Labourdette, 2011). Sediments within Section A can be interpreted as a 


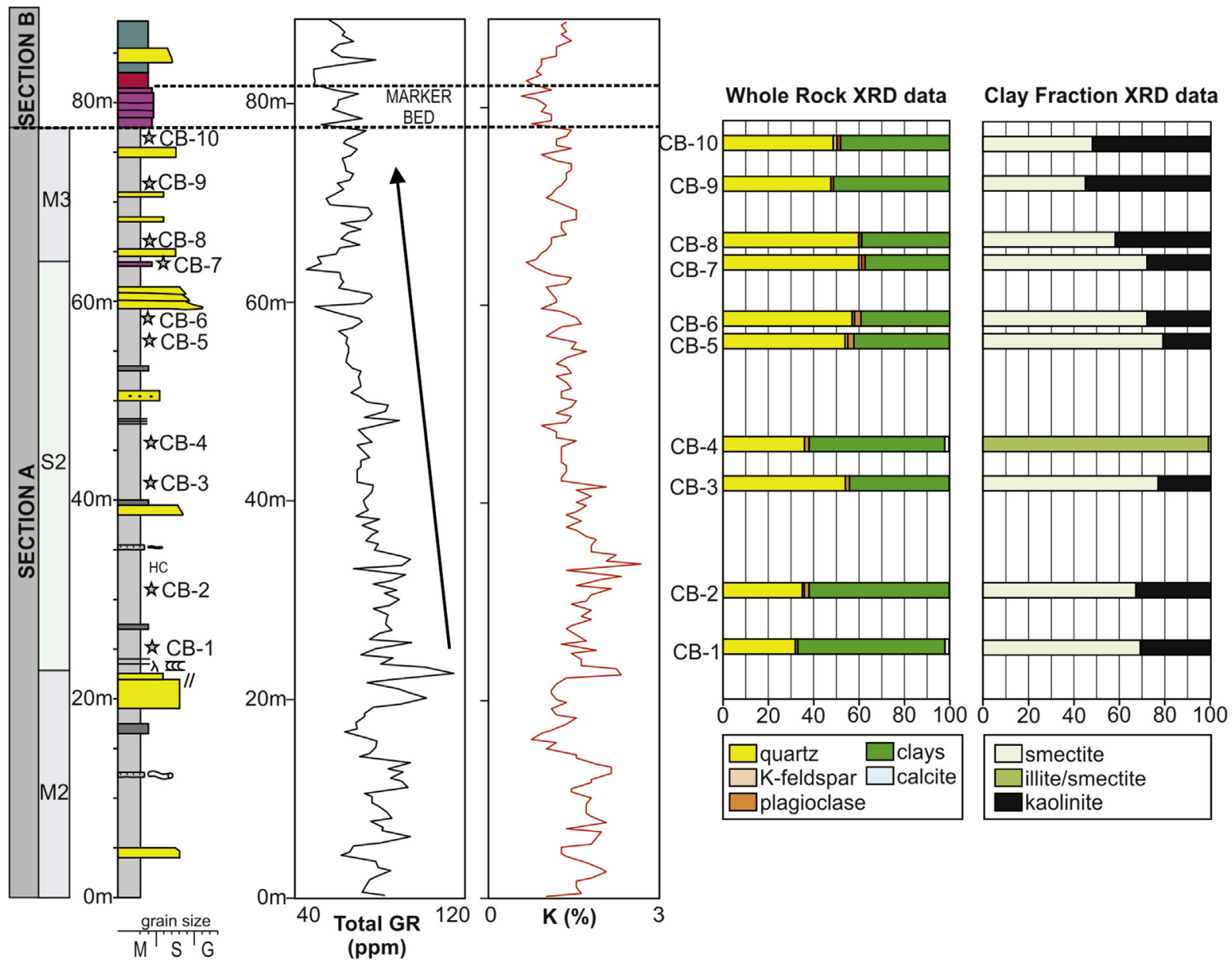

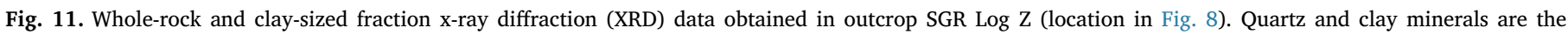

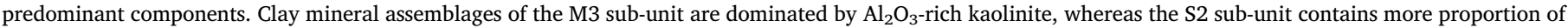
smectite.

high-accommodation systems tract due to the low interconnectivity of the channel belts, with a stacking density of $12 \%$. Channel belts of Section A are narrower than those of Section B, which can be associated with higher aggradation rate of floodplain materials in relation to avulsion frequency or channel migration rates. The sequence boundary is established by changing stacking patterns between Sections A and B, and also by the precise change in detrital composition (Miall and Arush, 2001).

On the other hand, Section B is considered a low-accommodation systems tract owing to the elevated connectivity of channel belts. Averaged stacking density of Section B is $32 \%$, reflecting reduced aggradation floodplain rate in relation to the lateral shift of the channel belts onto the floodplain. Besides, fluvial sequence models related to both base level shift and tectonic requires the occurrence of large incisional relief at base of amalgamated channel complexes (Miall, 2002) and coeval occurrence of mature paleosols in interfluves (Atchley et al., 2004; Hampson et al., 2005) to support base level shifts and the development of sequence boundaries Field observations and SGR correlations show that mudstone strata are virtually parallel in the Cerro Ballena area, indicating deposition of the stratigraphic intervals over a relatively flat relief. Lack of degradational features (e.g., incised valleys, fluvial terraces) also constitute indirect evidence of an aggradational system. The correlation of outcrop gamma-ray logs with well-logs of the Cerro Wenceslao oilfield (Fig. 10) indicates a layer-cake geometry of the studied fluvial succession over up to $15 \mathrm{~km}$ that we interpreted as evidence of negligible local tectonic activity in this part of the basin. Parallel seismic packages and no thickness variation of stratigraphic intervals within the Bajo Barreal Formation across faults (not shown) in the Cerro Wenceslao oilfield also reflect a lack of tectonic activity during deposition. However, it is worth mentioning that Upper Cretaceous tectonic activity in the Andean margin (Folguera and Iannizzotto, 2004; Folguera et al., 2011) would have increased the rate of production of volcanic particles and relief generation, which in turn could have produced larger volumes of volcaniclastic particles and a distinctive mineralogy in the coeval drainage systems. Hence, although the fluvial succession displays an overall aggradational pattern and shows no changes in the flow direction (Fig. 5), sudden variations in detrital modes and floodplain composition could be indirect evidence of coeval volcanic activity in the hinterlands (see Paredes et al., 2018a).

\subsection{Climatic control on staking and connectivity}

Climate changes occur in a quasi-periodic way at several scales (e.g., Milankovich cyclicity, see Imbrie et al., 1984), conditioning the delivery of water and sediment to fluvial basins, and vegetation cover (Leeder et al., 1998; Blum and Tornqvist, 2000; Blum and HattierWomack, 2009). River systems respond to climatic shifts in different forms, and the nature and amplitude of the climatic shifts necessary to generate a distinctive signal in current fluvial systems are currently not fully understood (Tandon and Sinha, 2007). Climate and channel stacking constitute a recurrent (and challenging) issue in the last decades (Olsen, 1994; Blum and Tornqvist, 2000; Heller et al., 2015) and a subject of active research (Foreman et al., 2012; Allen et al., 2013; Foreman, 2014; Simpson and Castelltort, 2012; Colombera et al., 2017; 


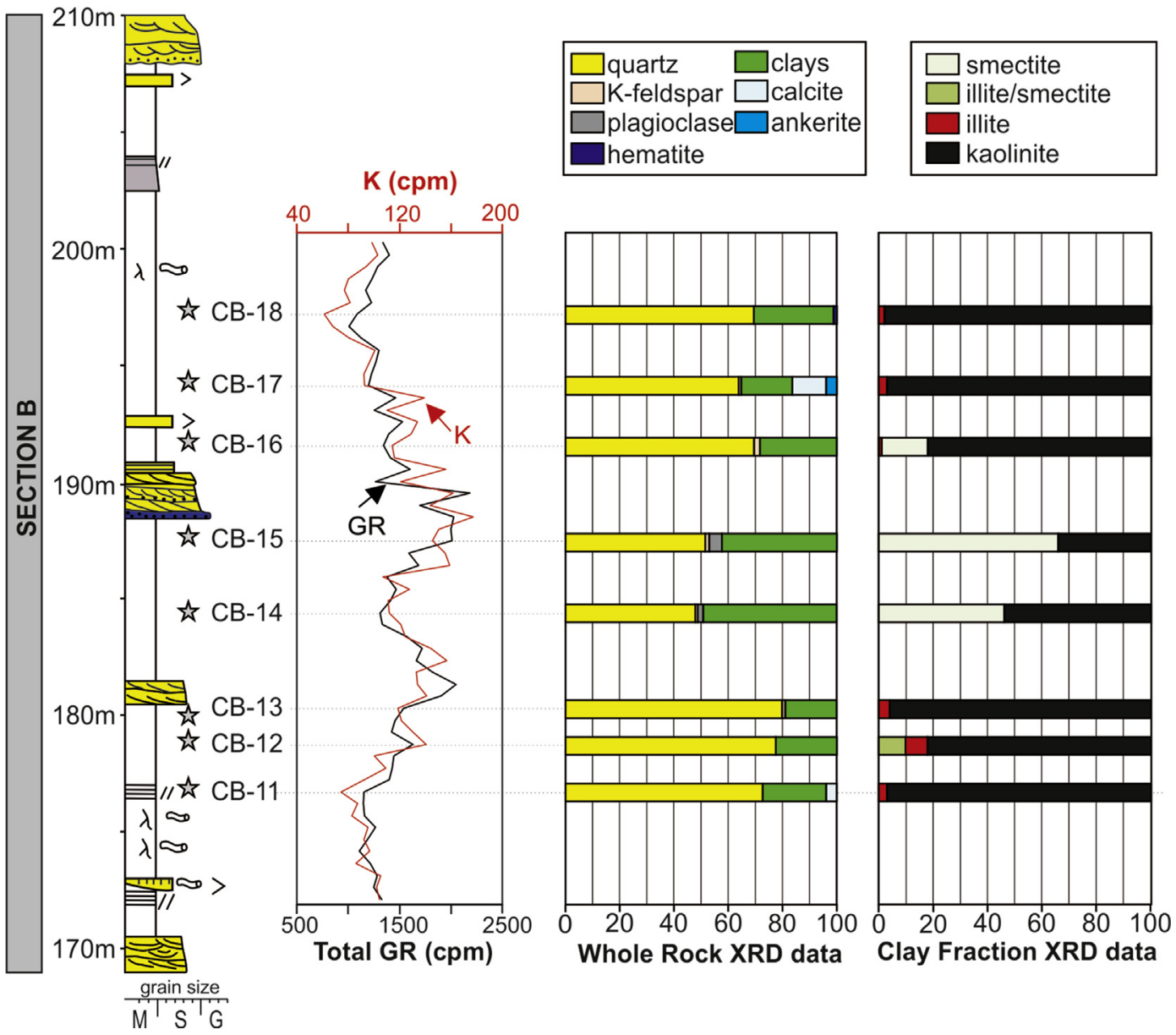

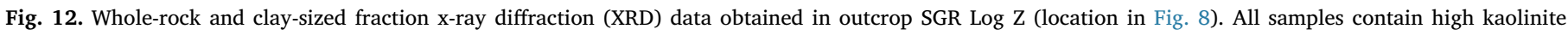
content, suggesting an increase in the weathering rate regarding Section A samples.

among others).

A detailed characterization of the channel fills in the Cerro Ballena exposures was provided by Paredes et al. (2018a), identifying an upward increase in both channel-fill width and flow depth toward Section B. In the study area, stratigraphic intervals with higher interconnectivity of channel deposits (Section B) contain wider and thicker channel bodies than intervals of lower interconnectivity of channel deposits (Section A). Based on the results of paleohydrological estimations (see Fig. 5), an upward shift toward more humid conditions was proposed. Further evidence of wetter conditions toward the uppermost part of the Cerro Ballena section has been presented in this research using outcrop spectral gamma-ray logs and x-ray diffraction analysis, where trends of change in both Total GR log and $\mathrm{K}$ contents seen to parallel changes in clay minerals in floodplain facies (see Figs. 9 and 10). Mainly, upward increases in kaolinite content through Section A are considered reliable evidence of increasing chemical weathering. Moreover, the observed (inverse) relation between Total GR values and kaolinite content in XRD analysis demonstrated that potassium hosted in clay minerals is the primary source of the radiation in the finegrained fraction.

Hajek and Heller (2012) pointed out that increases in water availability promote the further erosive capacity of the flow during floods and preservation of wider channel belts, removing a higher proportion of fines during floods and increasing the overall connectivity of channel deposits. The proposal implicitly states that climatic shifts can directly impact the connectivity of fluvial successions, through the generation of broader and deeper channel belts with higher connectivity during periods of high water availability. On the contrary, we can speculate on the occurrence of minor-scale, isolated single channels during stages of reduced water availability. As channel sizes are related to water availability and discharge of the formative rivers, our study demonstrates that a shift toward more humid conditions upward in the Cerro Ballena exposures has favored higher connectivity of the channelized sandstones. Besides, the study succession lacks age constraints necessary to infer aggradation rates; hence, temporal changes in accommodation regarding stacking density cannot be adequately evaluated. Furthermore, a recent evaluation of the inverse relation between channel-deposit proportion (and geometries) and floodplain aggradation rate values, do not follow the predicted behavior in fossil examples (Colombera et al., 2015), revealing the need of a profound revision of the fundamental principles of current fluvial stratigraphic models. In this regard, the present research demonstrates, using several independent lines of evidence, that climatic changes can control the variation in stacking density.

\subsection{Implication for subsurface studies}

In the subsurface, the results derived from this outcrop example can be applied to understand the origin of channel deposits of variable scale identified in stratigraphic intervals with different sand:mud ratio. Seismic attributes directly image the geometry of potential reservoirs, and constitute a common technique during oilfield development (Wood, 2007; Hubbard et al., 2011; El-Mowafy and Marfurt, 2016), providing relevant information for hydrocarbon production. In the Chubut Group of the Golfo San Jorge basin, it is common during oilfield development to identify stratigraphic intervals with vertical changes in the stacking pattern of channelized deposits (e.g., Catuneanu, 2019: his Fig. 14). Well-log information of upper levels of the Mina del Carmen 


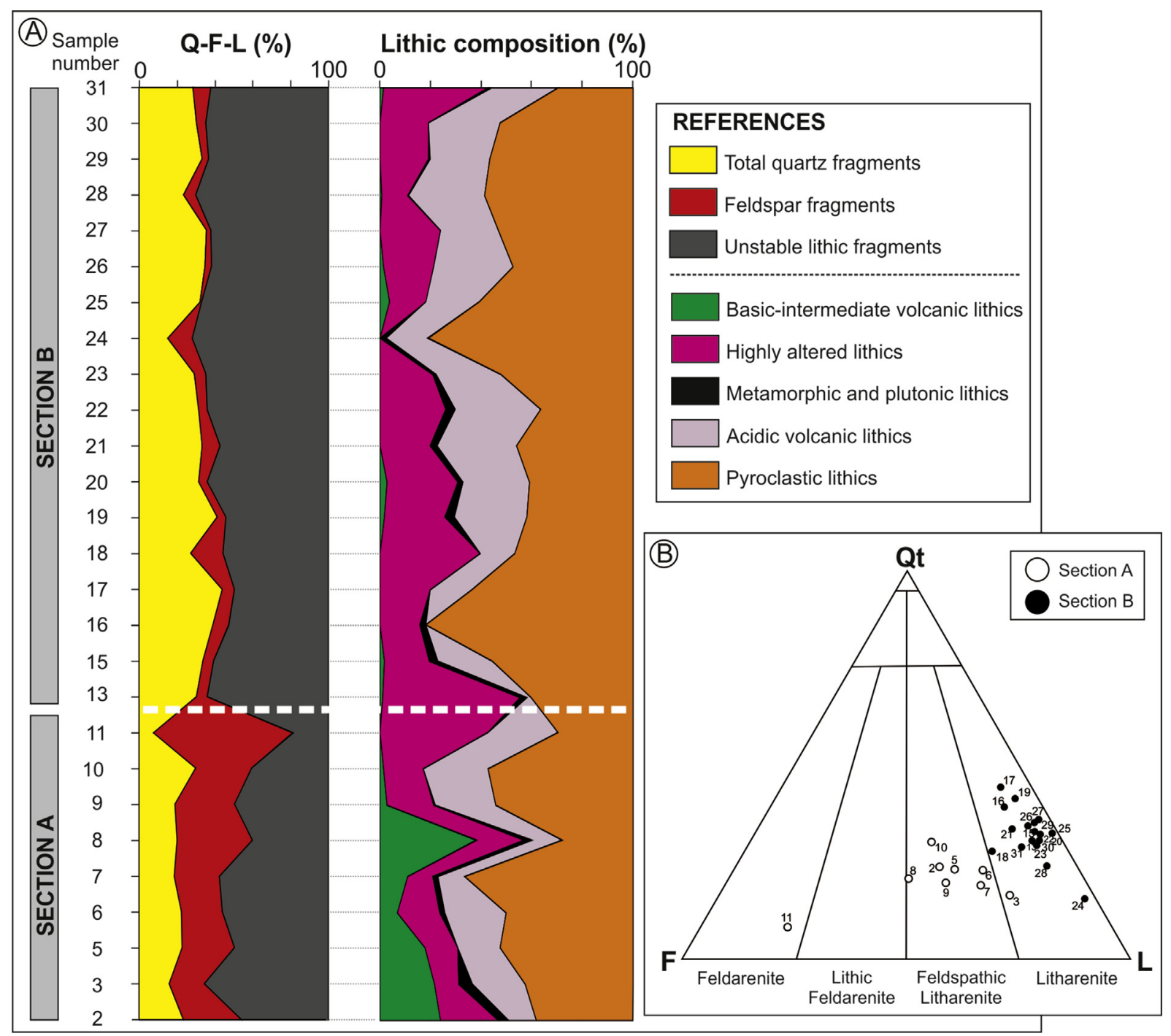

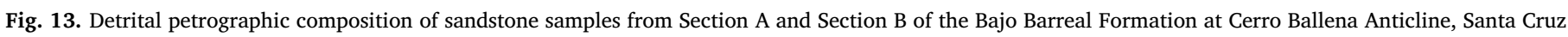

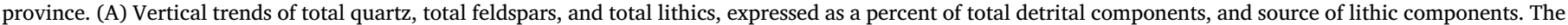

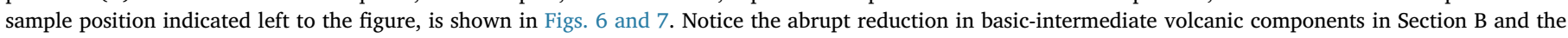

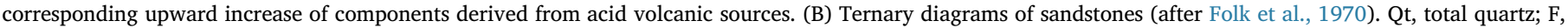
total feldspar; L, lithic fragments.

Formation in the El Cordón oilfield (Fig. 14A, location in Fig. 1) show channel fills separated by thick floodplain fines, whereas in the Caleta Olivia Member of the Cañadón Seco Formation (equivalent to the Lower Bajo Barreal Formation) channels are thicker and floodplain fines are in lower proportion. The visualization of channel belts was performed using spectral decomposition volumes (see Partyka et al., 1999), allowing to define channel margins, true width of the channels, and patterns of displacement of channel belts in the interval of interest. A blend of frequencies from individual volumes in the range of $24-56 \mathrm{~Hz}$ was imaged, visualizing the geometries of channel belts from a seismic horizon (H2) within the Mina del Carmen Formation (location in Fig. 1) and from the top of the Mina del Carmen Formation (H1). In the seismic volume around $\mathrm{H} 1$, we considered, due to a large number of channelized features, that most of the geobodies belong to the Caleta Olivia Member.

By using spectral decomposition in the $\mathrm{H} 2$ seismic horizon (Upper Mina del Carmen Formation) several low-sinuosity fluvial channels with variable orientation are identified, with channel-body widths in the order of $140-200 \mathrm{~m}$. On the other hand, fluvial channels imaged within the Caleta Olivia Member are of high-sinuosity and larger scale, with channel-fill widths up to $450 \mathrm{~m}$, and channel-belt widths commonly up to $2500 \mathrm{~m}$. Hence, stratigraphic intervals of higher sand:mud ratio display wider fluvial channels that those of lower sand:mud ratio, where narrow fluvial channels predominate. Although the natural variability of the fluvial systems is extremely high, and no general rules can be derived from this single example, our analysis of the Bajo Barreal Formation have provided a reliable example in which the stacking (and hence inter-connectivity) of fluvial channels occur synchronously with variations in the scale (true width, flow depth?) and style of the formative rivers. From this, the identification of climatic cycles in the subsurface can be attempted through the integration of spectral gamma-ray logs and clay mineralogy changes plus imaging of fluvial geobodies using seismic attributes. The integration of results derived from the present approach, with palaeohydrological estimations derived from morphometric parameters of imaged channel belts using empirical relations obtained for current rivers (Reijenstein et al., 2011; Wood, 2007; Musial et al., 2012) constitute a promising field of research in order to assess climatic variation associated with changes in channel dimensions in the subsurface environment. 

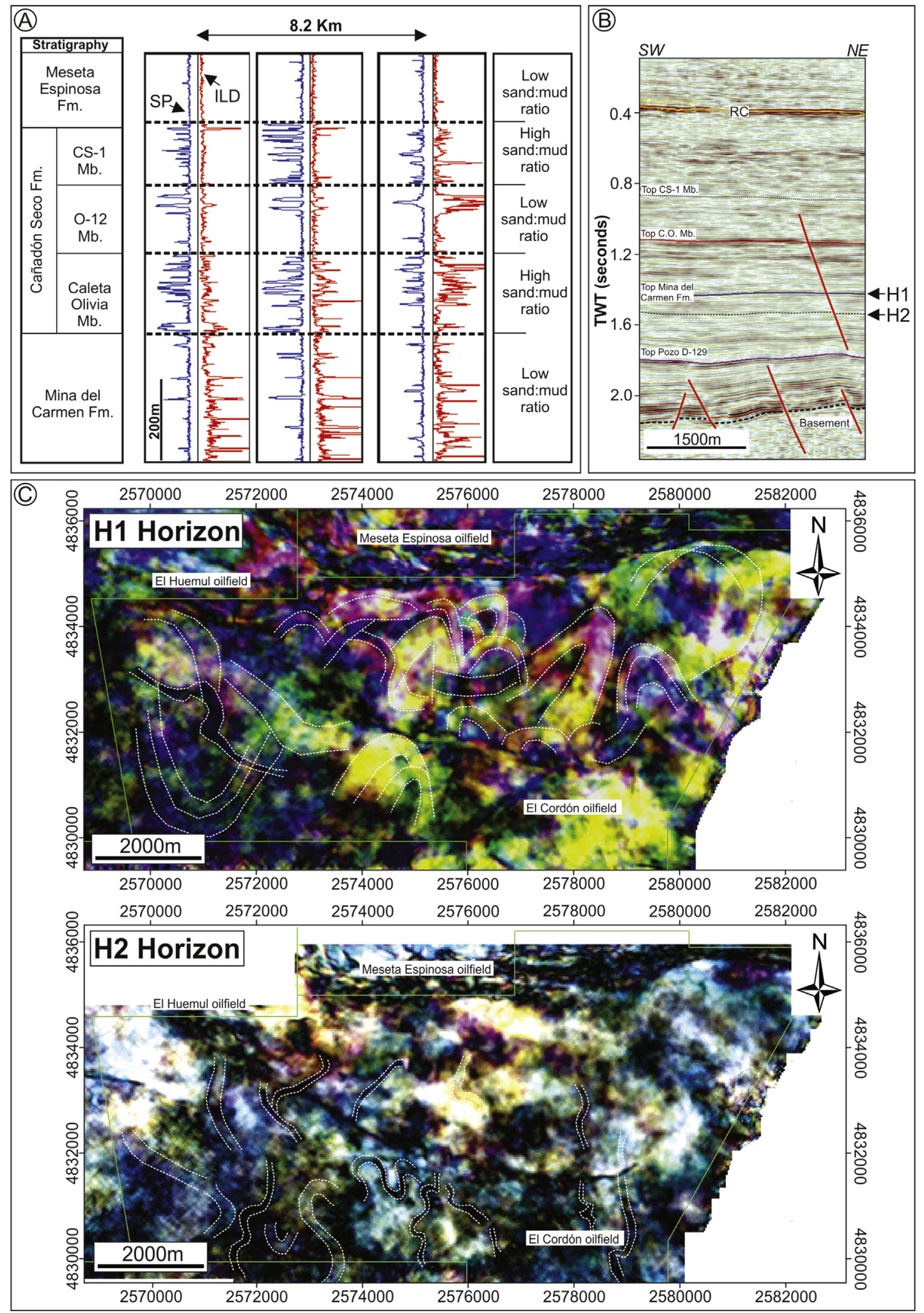

Fig. 14. Variability in stacking of the Bajo Barreal Formation in the El Cordón oilfield (location in Fig. 1). (A) The stratigraphic pattern of Mina del Carmen and Cañadón Seco formations, with alternating packages of high and low sand:mud ratio. (B) Techniques of channel visualizations applied to a seismic horizon within the Mina del Carmen Formation (H2) and to a seismic horizon close to the top of the Mina del Carmen Formation (H1). (C) Comparison of channel dimensions of channel fills visualized in the Mina del Carmen Formation and Caleta Olivia Member of the Cañadón Seco Formation. 


\section{Concluding remarks}

Fluvial deposits of the Bajo Barreal Formation (Upper Cretaceous) record deposition of contrasting styles of stacking (e.g., isolated vs. highly interconnected channel fills) among two distinctive lithological sections in the Cerro Ballena anticline. Rooted in a published sedimentological study that recognized increases in both channel width and flow depth upward of the studied succession, and hence the temporal increase in river discharge and water availability, we collect information recording three spectral gamma-ray logs, eighteen $\mathrm{x}$-ray diffraction data of mudstone samples, and petrography of sandstones within 31 channel fills. The conclusion includes the following.

1. We interpreted a nearly flat geomorphic scenario for the study succession based in the correlation of distinctive log motifs within Section A in outcrop spectral gamma-ray logs, with subsurface gamma-ray logs in the Cerro Wenceslao oilfield, distant up to $12 \mathrm{~km}$ from the outcrops. The layer-cake distribution, lack of either largescale erosional surfaces, terraces, or evident paleosol successions, and relatively constant paleoflow directions (the later feature identified in Paredes et al., 2018a, b) suggest lack of either local tectonic activity or base-level shifts during deposition.

2. The integration of results derived from the SGR logs and XRD diffraction analysis revealed a genetic link between both Total GR values and $\mathrm{K}$ content with the proportion of different clay minerals. An upward K reduction through Section A identified using spectral gamma-ray logs parallel with the increase in kaolinite content in XRD analysis of mudstones. Increase in kaolinite content is also the likely reason of lower radiation values observed in the Total GR log toward upper levels of Section A. Within Section B, mudstone samples have higher proportion of kaolinite content that samples in Section A. These results can be integrated with previous paleohydrological estimations of the studied succession, supporting a climatic shift toward more humid conditions in upper levels of the Cerro Ballena Anticline.

3. The detrital provenance of Section A indicates the mixing of volcanic components, which were derived mainly from acidic sources in the coeval Andes Cordillera, with basic-intermediate sources derived from the middle Jurassic Bahía Laura Group in the Deseado Massif. Samples from Section A are feldspathic litharenites, litharenites and feldsarenites with modal averages $\mathrm{Q}_{20} \mathrm{~F}_{33} \mathrm{~L}_{47}$ and $\mathrm{Lm}_{1} \mathrm{Lv}_{99} \mathrm{Ls}_{0}$, and moderate contribution of intermediate to basic volcanic fragments (average 14\%). Samples from Section B contain an abundance of volcaniclastic, mainly pyroclastic, compositions derived exclusively from the Andes Cordillera, corresponding to litharenites with a modal average of $\mathrm{Q}_{31} \mathrm{~F}_{7} \mathrm{~L}_{62}$ and $\mathrm{Lm}_{1} \mathrm{Lv}_{99} \mathrm{Ls}_{1}$, and reflect a significative reduction in both $\mathrm{K}$ content and intermediatebasic components.

4. A major reorganization of the fluvial system occurs at the boundary between Section A and Section B, where synchronic changes in (i) bedload composition, (ii) suspended-load type, and (iii) channel sizes (width, flow depth) is coincident with changes in the stacking density and inter-connectivity of fluvial channels. The most probable reason for the upward increase of the sand:mud ratio is a significative increase in both sediment supply and discharge of the rivers, which could generate either the increasing frequency of channel avulsion or higher channel migration rates. Thus, our approach combining several independent techniques indicate that climate changes can directly impact on the stacking and connectivity of potential sandstone reservoirs.

5. The integration of outcrop methodologies presents future research opportunities and challenges for subsurface environments. Our example of an oil-bearing fluvial succession in the nearby El Cordón oilfield reveals that stratigraphic intervals with high sand:mud ratio is characterized by large-scale fluvial channels with a meandering pattern, whereas intervals of low sand:mud ratio show low- sinuosity, narrow fluvial channels. Thus, it is likely that the correspondence between vertical stacking changes, as identified in wireline logs, and variation in the style and scale of the fluvial channels using seismic attributes, can be integrated with geochemical information linked to temporal variations in the chemical weathering throughout (geochemical profiles, XRD, SGR logs), being helpful to identify climatic cycles in the subsurface record.

\section{Acknowledgments}

We want to thank SINOPEC ARGENTINA E\&P for permission to publish the results. The Departamento de Geología (FCNyCS-UNPSJB) is acknowledged for logistic support. The authors are indebted to landowners of estancia Cañadon Vasco (family Bain) for access to outcrops. M.E. Covo is thanked for preparing Fig. 14. We are sincerely grateful for the detailed and insightful reviews provided by Dr. Luis A. Spalletti (UNLP, CONICET) and Giorgio Basilici (UNICAMP-Brazil), and Associate Editor Dr. Luca Colombera, whose comments helped us to improve clarity and focus.

\section{Appendix A. Supplementary data}

Supplementary data to this article can be found online at https:// doi.org/10.1016/j.marpetgeo.2019.104116.

\section{References}

Allard, J.O., Paredes, J.M., Foix, N., Giacosa, R.E., 2015. Conexión cretácica entre las cuencas del Golfo San Jorge y Cañadón Asfalto (Patagonia): paleogeografía, implicancias tectonoestratigráficas y su potential en la exploración de hidrocarburos. Rev. Asoc. Geol. Arg. 72, 21-37.

Allen, J.R.L., 1978. Studies in fluviatile sedimentation: an exploratory quantitative model for architecture of avulsion-controlled alluvial suites. Sediment. Geol. 21, 129-147.

Allen, J.P., Fielding, C.R., Rygel, M.C., Gibling, M.R., 2013. Deconvolving signals of tectonic and climatic controls from continental basins: an example from the late Paleozoic Cumberland Basin, Atlantic Canada. J. Sediment. Res. 83, 847-872.

Allen, J.P., Fielding, C.R., Gibling, M.R., Rygel, M.C., 2014. Recognizing products of palaeoclimate fluctuations in the fluvial stratigraphic record: an example from the Pennsylvanian to lower Permian of Cape Breton Island, Nova Scotia. Sedimentology 61, 1332-1381.

Archangelsky, S., Bellosi, E., Jalfin, G.A., Perrot, C., 1994. Palynology and alluvial facies from mid-cretaceous of Patagonia, subsurface of san Jorge basin, Argentina. Cretac. Res. 15, 127-142.

Atchley, S.C., Nordt, L.C., Dworkin, S.I., 2004. Eustatic control on alluvial sequence stratigraphy: a possible example from the Cretacous-Tertiary transition of the Tornillo Basin, Big Bend National Park, west Texas, USA. J. Sediment. Res. 74, 391-404.

Barcat, C., Cortiñas, J., Nevistic, V., Zucchi, H., 1989. Cuenca Golfo san Jorge. In: In: Chebli, G., Spalletti, L.A. (Eds.), Cuencas Sedimentarias Argentinas, vol. 6. Universidad Nacional de Tucumán, Serie Correlación Geológica, pp. 319-345.

Blum, M.D., Tornqvist, T.E., 2000. Fluvial responses to climate and sea-level change: a review and look forward. Sedimentology 47, 2-48.

Blum, M.D., Hattier-Womack, J., 2009. Climate change, sea-level change, and fluvial sediment supply to deepwater systems. In: In: Kneller, B., Martinsen, O.J., McCaffrey, B. (Eds.), External Controls on Deep Water Depositional Systems: Climate, Sea-Level, and Sediment Flux, vol. 92. SEPM Special Publication, pp. 15-39.

Bridge, J.S., Mackey, S.D., 1993. A theoretical study of fluvial sandstone body dimensions. In: In: Flint, S.S., Bryant, I.D. (Eds.), Geological Modeling of Hydrocarbon Reservoirs, vol. 15. International Association of Sedimentologists, Special Publication, pp. 213-236.

Bridge, J.S., Leeder, M.R., 1979. A simulation model of alluvial stratigraphy. Sedimentology 26, 617-644.

Bridge, J.S., Tye, R.S., 2000. Interpreting the dimensions of ancient fluvial channel bars, channels, and channel belts from wireline-logs and cores. AAPG (Am. Assoc. Pet. Geol.) Bull. 84, 1205-1228.

Bridge, J.S., Jalfin, G.A., Georgieff, S.M., 2000. Geometry, lithofacies, and spatial distribution of Cretaceous fluvial sandstone bodies, San Jorge Basin, Argentina: outcrops analog for the hydrocarbon-bearing Chubut Group. J. Sediment. Res. 70, 319-337.

Brown, L.F., Barcat, C., Fisher, L.W., Nevistic, A., 1982. Seismic stratigraphic and depositional systems analysis: new exploration approaches applied to the Gulf of San Jorge Basin, Argentina. In: 1st Congreso Nacional de Hidrocarburos, Petróleo y Gas, pp. 127-156 (Mar del Plata).

Bryant, M., Falk, P., Paola, C., 1995. Experimental study of avulsion frequency and rate of deposition. Geology 23, 365-368.

Casal, G.A., Allard, J.O., Foix, N., 2015. Análisis estratigráfico y paleontológico del Cretácico Superior en la Cuenca del Golfo San Jorge: nueva unidad litoestratigráfica para el Grupo Chubut. Rev. Asoc. Geol. Arg. 72, 81-99. 
Catuneanu, O., 2006. Principles of Sequence Stratigraphy. Elsevier, Oxford, pp. 375. Catuneanu, O., 2019. Scale in sequence stratigraphy. Mar. Pet. Geol. 106, 128-159.

Chamberlin, E.P., Hajek, E.A., 2015. Interpreting paleo-avulsion dynamics from multistorey sand bodies. J. Sediment. Res. 85, 82-94.

Chamley, H., 1989. Clay Sedimentology. Springer, Berlin, pp. 623.

Clavijo, R., 1986. Estratigrafía del cretácico inferior en el sector Occidental de la Cuenca Golfo San Jorge. Bol. Inf. Pet. (1924) 9, 15-32 (Buenos Aires).

Cobos, J.C., Panza, J.L., 2003. Hola geológica 4769-1 (el pluma). Serv. Geol. Min. Argent. Bol. 319, 1-89 (Buenos Aires).

Colombera, L., Mountney, N.P., Williams, W.D., 2015. A meta-study of relationships between fluvial channel-body stacking pattern and aggradation rate: implications for sequence stratigraphy. Geology 43 (4), 283-286.

Colombera, L., Arévalo, O.J., Mountney, N.P., 2017. Fluvial-system response to climate change: the paleocene-eocene tremp Group, pyrenees, Spain. Glob. Planet. Chang. $157,1-17$.

Colombo, F., 1994. Normal and reverse unroofing sequences in syntectonic conglomerates as evidence of progressive basinward deformation. Geology 22, 235-238.

Corbeanu, R.M., Soegaard, K., Szerbiak, R.B., Thurmond, J.B., McMechan, G.A., Wang, D., Snelgrove, S., Forster, C.B., Menitove, A., 2001. Detailed internal architecture of a fluvial channel sandstone determined from outcrop, cores and 3-D ground-penetrating radar: example from the middle Cretaceous Ferroan Sandstone, east-central Utah. AAPG (Am. Assoc. Pet. Geol.) Bull. 85, 1583-1608.

Davies, N.S., Gibling, M.R., 2010. Cambrian to Devonian evolution of alluvial systems: the sedimentological impact of the earliest land plants. Earth Sci. Rev. 98, 171-200.

Davies, N.S., Gibling, M.R., Rygel, M.C., 2011. Alluvial facies during the Palaeozoic greening of the land: case studies, conceptual models and modern analogues. Sedimentology 58, 220-258.

Dickinson, W.R., 1970. Interpreting detrital modes of graywacke and arkose. J. Sediment. Petrol. 40, 695-707.

Dickson, J.A.D., 1966. Carbonate identification and genesis as revealed by staining. J. Sediment. Petrol. 36, 491-505.

Di Benedetto, L., Georgieff, S.M., Potas, G., 2006. Stratigraphic correlation and sedimentary analogs: Ballena hill outcrops and Cañadón Vasco oil field, southern flank of san Jorge basin, Argentina. In: Simposio Bolivariano de Hidrocarburos, Cartagena de Indias, Colombia.

Drief, A., Nieto, F., 2000. Chemical composition of smectites formed in clastic sediments. Implications for the smectite-illite transformation. Clay Miner. 35, 665-678.

Dunn, T.L., 1992. Infiltrated materials in cretaceous volcanogenic sandstones, san Jorge basin, Argentina. In: In: Houseknecht, D.W., Pittman, E.D., Lidz, B.H. (Eds.), Origin, Diagenesis and Petrophysics of Clay Minerals in Sandstones, vol. 47. SEPM (Society for Sedimentary Geology) Special Publication, pp. 159-174.

El-Mowafy, H.Z., Marfurt, K.J., 2016. Quantitative seismic geomorphology of the middle Frio fluvial systems, south Texas, United States. AAPG (Am. Assoc. Pet. Geol.) Bull. 100 (4), 537-564.

Ethridge, F.G., Schumm, S.A., 2007. Fluvial seismic geomorphology. In: In: Davies, R., Posamentier, H.W., Wood, L.J., Cartwright, J. (Eds.), Seismic Geomorphology: Application to Hydrocarbon Exploration and Production, vol. 277. Geological Society of London, Special Publication, pp. 205-222.

Evans, R., Mory, A.J., Tait, A.M., 2007. An outcrop gamma ray study of the Tumblagooda Sandstone, Western Australia. J. Pet. Sci. Eng. 57, 37-59.

Feruglio, E., 1949. Descripción geológica de la Patagonia. Yacimientos pet. Fisc 2, 1-349 (Buenos Aires).

Figari, E.G., Hechem, J.J., Homovc, J.F., 1990. Arquitectura depositacional de las "Areniscas Verdes" de la Formación Bajo Barreal, provincia del Chubut, Argentina. In: 3rd Reunión Argentina de Sedimentología, vol. 1. pp. 130-138 (San Juan).

Figari, E.G., Courtade, S.F., Calegari, R., Arroyo, H., Constantini, L., 1998. Estructura y estratigrafía del Cerro Ballena. In: Faja Plegada meridional de la Cuenca del Golfo San Jorge. X Congreso Latinoamericano de Geología y VI Congreso Nacional de Geología Económica, vol. I. pp. 18-23 (Buenos Aires).

Fitzgerald, M.G., Mitchum, R.M., Uliana, M.A., Biddle, K.T., 1990. Evolution of the san Jorge basin, Argentina. AAPG (Am. Assoc. Pet. Geol.) Bull. 74, 879-920.

Folguera, A., Iannizzotto, N., 2004. The Lagos La Plata and Fontana fold-and-thrust belt: long-lived orogenesis at the edge of western Patagonia. J. South Am. Earth Sci. 16, 541-566.

Folguera, A., Orts, D., Spagnuolo, M., Rojas Vera, E., Litvak, V., Sagripanti, L., Ramos, M.E., Ramos, V.A., 2011. A review of late Cretaceous to Quaternary palaeogeography of the southern Andes. Biol. J. Linn. Soc. 103, 250-268.

Folk, R.L., Andrews, P.B., Lewis, D., 1970. Detrital sedimentary rock classification and nomenclature for use in New Zealand. N. Z. J. Geol. Geophys. 13, 937-968.

Foreman, B.Z., 2014. Climate-driven generation of a fluvial sheet sand body at the Paleocene-Eocene boundary in north-west Wyoming (USA). Basin Res. 26, 225-241.

Foreman, B.Z., Heller, P.L., Clementz, M.T., 2012. Fluvial response to abrupt global warming at the Palaeocene/Eocene boundary. Nature 491, 92-95.

Galán, E., 2006. Genesis of clay minerals. In: In: Berhaya, F., Theng, B.K.G., Lagaly, G. (Eds.), Handbook of Clay Science, Developments in Clay Science, vol. 1. Elsevier, The Netherlands, pp. 1129-1162.

Garzanti, E., Vezzoli, G., 2003. A classification of metamorphic grains in sands based in their composition and grade. J. Sediment. Res. 73, 830-837.

Georgieff, S.M., Sosa Gómez, J.A., Ferreira, L., Vides, M.E., Ibañez, L.M., Ovejero, R., Bossi, G.E., Richter, G.A.V., Anis, K.B., Pieroni, E.M., Moyano, S., 2009. Characterization of fluvial sandstones in the cerro guadal norte oil field, Golfo san Jorge basin, Santa Cruz, Argentina. In: 9th International Conference on Fluvial Sedimentology, pp. 35-36 (San Miguel de Tucumán, Argentina).

Ghasemi-Nejad, E., Ardakani, E.P., Ruffell, A., 2010. Palaeoclimate change recorded in upper cretaceous (Albian-Cenomanian) kazhdumi formation borehole SPECTRAL gamma-ray logs, south pars gas field, Persian Gulf. Paleogeogr., Palaeoclimatol.,
Palaeoecol. 291, 338-347.

Ghinassi, M., Ielpi, A., Aldinucci, M., Fustic, M., 2016. Downstream-migrating fluvial point bars in the rock record. Sediment. Geol. 334, 66-96.

Giampaoli, P., 2019. Cretaceous extensional systems of the Golfo San Jorge basin: insights from the analysis of fault length and displacement data. J. South Am. Earth Sci. 92, 298-309.

Graham, S.A., Tolson, R.B., Decelles, P.G., Ingersoll, R.V., Bargar, E., Caldwell, M., Cavazza, W., Edwards, D.P., Follo, M.F., Handschy, J.F., Lemke, L., Moxon, I., Rice, R., Smith, G.A., White, J., 1986. Provenance modeling as a technique for analyzing source terrane evolution and controls on foreland sedimentation. In: In: Allen, P.A., Homewood, P. (Eds.), Foreland Basins: International Association of Sedimentologists, vol. 8. Special Publication, pp. 425-436.

Hajek, E.A., Heller, P.L., 2012. Flow-depth scaling in alluvial architecture and nonmarine sequence stratigraphy: example from the Castlegate Sandstone, Central Utah. U.S.A: J. Sediment. Res. 82, 121-130.

Hajek, E.A., Wolinsky, M.A., 2012. Simplified process modeling of river avulsion and alluvial architecture: connecting models and field data. Sediment. Geol. 257, 1-30.

Hampson, G.J., Davies, W., Davies, S.J., Howell, J.A., Adamson, K.R., 2005. Use of spectral gamma-ray data to refine subsurface fluvial stratigraphy: late Cretaceous strata in the Book Cliffs, Utah, USA. J. Geol. Soc. 162, 603-621 London.

Hechem, J.J., 1994. Modelo predictivo de reservorios en un sistema fluvial efímero del Chubutiano de la cuenca del Golfo San Jorge, Argentina. Rev. Asoc. Arget. de Sediment. 1, 3-14.

Hechem, J.J., 1997. Arquitectura y paleodrenaje del sistema fluvial efímero de la Formación Bajo Barreal, cuenca del Golfo San Jorge, Argentina. In: 1st Congreso Latinoamericano de Sedimentología, Actas, vol. 1. pp. 315-323 (Isla Margarita, Venezuela).

Hechem, J.J., Homovc, J.F., Figari, E.G., 1990. Estratigrafía del Chubutiano (Cretácico) en la Sierra de San Bernardo, cuenca del Golfo San Jorge, Argentina. In: 11th Congreso Geológico Argentino, Actas, vol. 3. pp. 173-176 (San Juan).

Heller, P.L., Ratigan, D., Trampush, S., Noda, A., McElroy, B., Drever, J., Huzurbazar, S., 2015. Origins of bimodal stratigraphy in fluvial deposits: an example from the Morrison Formation (Upper Jurassic), western. U.S.A. J. Sediment. Res. 85, $1466-1477$.

Homovc, J.F., Conforto, G.A., Lafourcade, P.A., Chelotti, L.A., 1995. Fold Belt in the San Jorge basin, Argentine: an example of tectonic inversion. In: In: Buchanan, J.G., Buchanan, P.G. (Eds.), Basin Inversion, vol. 88. Geological Society of London, Special Publication, pp. 235-248.

Hubbard, S.M., Smith, D.G., Nielsen, H., Leckie, D.A., Fustic, M., Spencer, R.J., Bloom, L., 2011. Seismic geomorphology and sedimentology of a tidally influenced river deposit, Lower Cretaceous Athabasca oil sands, Alberta, Canada. AAPG (Am. Assoc. Pet. Geol.) Bull. 95, 1123-1145.

Ibañez, L.M., Ovejero, R., Georgieff, S.M., Ferreira, L., Bossi, G., 2015. Petrografía y porosidad de areniscas portadoras de petróleo. Formación Bajo Barreal (Cretácico), Cuenca Golfo San Jorge, Argentina. Acta Geol. Lilloana 27, 29-51.

Imbrie, J., Hays, J.D., Martinson, D.G., McIntyre, A., Mix, A.C., Moreley, J.J., Pisias, N.G., Prell, W.L., Shackleton, N.J., 1984. The orbital theory of Pleistocene climate: support from the revised chronology of the $\mathrm{d} 180$ record. In: Berger, A., Imbrie, J., Hays, J., Kukla, G., Saltzman, B. (Eds.), Milankovitch and Climate. Reidel, Dordrecht, pp. 269-306.

Ingersoll, R.V., 1978. Petrofacies and petrologic evolution of the Late Cretaceous fore-arc basin, northern and central California. J. Geol. 86, 335-352.

Ingersoll, R.V., Cavazza, W., 1991. Reconstruction of Oligo-Miocene volcaniclastic dis persal patterns in North-Central New Mexico using sandstone petrofacies. In: In: Fisher, R.V., Smith, G.A. (Eds.), Sedimentation in Volcanic Settings, vol. 45. SEPM (Society for Sedimentary Geology) Special Publication, pp. 227-236.

Ingersoll, R.V., Bullard, T.F., Ford, R.L., Grimm, J.P., Pickle, J.D., Sares, S.W., 1984. The effect of grain size on detrital modes: a test of the Gazzi-Dickinson point-counting method. J. Sediment. Petrol. 54, 103-116.

Karssenberg, D., Tornqvist, T.E., Bridge, J.S., 2001. Conditioning a process-based model of sedimentary architecture to well data. J. Sediment. Res. 71, 868-879.

Keeton, G.I., Pranter, M.J., Cole, R.D., Gustason, E.R., 2015. Stratigraphic architecture of fluvial deposits from borehole images, spectral-gamma-ray response, and outcrop analogs, Piacense Basin, Colorado. AAPG (Am. Assoc. Pet. Geol.) Bull. 99, 1929-1956.

Keogh, K.J., Leary, S., Martinius, A.W., Scott, A.S.J., Riordan, S., Viste, I., Gowland, S., Taylor, A.M., Howell, J., 2014. Data capture for multiscale modelling of the lourinhã formation, lusitanian basin, Portugal: an outcrop analogue for the statfjord Group, Norwegian north sea. In: In: Martinius, A.W., Howell, J.A., Good, T.R. (Eds.), Sediment-Body Geometry and Heterogeneity: Analogue Studies for Modelling the Subsurface, vol. 387. Geological Society of London, Special Publications, pp. 27-56.

Kjemperud, A.V., Schomacker, E.R., Cross, T.A., 2008. Architecture and stratigraphy of alluvial deposits, morrison formation (upper jurassic), Utah: AAPG. Am. Assoc. Petrol. Geol. Bull. 92, 1055-1076.

Labourdette, R., 2011. Stratigraphy and static connectivity of braided fluvial deposits of the lower Escanilla Formation, south central Pyrenees, Spain. AAPG (Am. Assoc. Pet. Geol.) Bull. 95, 585-617.

Leclair, S.F., 2002. Preservation of cross strata due to migration of subaqueous dunes: an experimental investigation. Sedimentology 49, 1157-1180.

Leclair, S.F., Bridge, J.S., 2001. Quantitative interpretation of sedimentary structures formed by river dunes. J. Sediment. Res. 71, 713-716.

Leeder, M.R., 1978. A quantitative stratigraphic model for alluvium, with special reference to channel deposit density and interconnectedness. Can. Soc. Pet. Geol. Mem. 5, 587-596.

Leeder, M.R., Harris, T., Kirkby, M.J., 1998. Sediment supply and climate change: implications for basin stratigraphy. Basin Res. 10, 7-18. 
Legarreta, L., Uliana, M., Larotonda, C.A., Meconi, G.R., 1993. Approaches to nonmarine sequence stratigraphy - theoretical models and examples from Argentine basins. In: In: Eschard, R., Doliez, B. (Eds.), Subsurface Reservoir Characterization from Outcrop Observations. Collection Colloques et Séminaires, vol. 51. Editions Technip, Paris, pp. 125-145.

Lesta, P., 1968. Estratigrafía de la Cuenca del Golfo San Jorge. In: 3rd Jornadas Geológicas Argentinas, Actas, vol. 1. pp. 251-280 (Buenos Aires).

Lesta, P., Ferello, R., 1972. Región Extraandina del Chubut y norte de Santa Cruz. In: Leanza, A. (Ed.), Geología Regional Argentina. Academia Nacional de Ciencias, Córdoba, pp. 601-654.

Lesta, P., Ferello, R., Chebli, G., 1980. Chubut extraandino. In: In: Turner, J.C. (Ed.), II Simposio de Geología Regional Argentina, vol. 2. Academia Nacional de Ciencias, Córdoba, pp. 1307-1387.

Limarino, C.O., Giordano, S.R., 2016. Unraveling multiple provenance areas using sandstone petrofacies and geochemistry: an example in the southern flank of the Golfo San Jorge Basin (Patagonia, Argentina). J. South Am. Earth Sci. 66, 208-231.

Limarino, C.O., Giordano, S.R., Rodriguez Albertani, R.J., 2017. Diagenetic model of the Bajo Barreal Formation (cretaceous) in the southwestern flank of the Golfo de San Jorge Basin (Patagonia, Argentina). Mar. Pet. Geol. 88, 907-931.

Lindgreen, H., Surlyk, F., 2000. Upper Permian-Lower Cretaceous clay mineralogy of East Greenland: provenance, palaeoclimate and volcanicity. Clay Miner. 35, 791-806.

Mack, G.H., Leeder, M.R., 1998. Channel shifting of the Rio Grande, southern Rio Grande rift: implications for alluvial stratigraphic models. Sediment. Geol. 117, 207-219.

Martinsen, O., Ryseth, A., Hansen, W.H., Fleshe, H., Torkildsen, G., Idil, S., 1999. Stratigraphic base level and fluvial architecture: ercson sandstonw (campanian), rock springs uplift, SW Wyoming, USA. Sedimentology 46, 235-259.

McKinley, G.A., Follows, M.J., Marshall, J., Fan, S., 2003. Interannual variability in air sea $\mathrm{O}_{2}$ fluxes and the determination of $\mathrm{CO}_{2}$ sinks using atmospheric $\mathrm{O}_{2} / \mathrm{N}_{2}$. Geophys. Res. Lett. 30, 1101-1104.

Miall, A.D., 2002. Architecture and sequence stratigraphy of Pleistocene fluvial systems in the Malay Basin based on seismic time-slice analysis. AAPG (Am. Assoc. Pet. Geol.) Bull. 86, 1201-1216.

Miall, A.D., Arush, M., 2001. The Castlegate Sandstone of the Book Cliffs, Utah: sequence stratigraphy, paleogeography, and tectonic controls. J. Sediment. Res. 71, 537-548.

Millot, G., 1970. Geology of Clays. Springer, New York, pp. 429.

Moore, D., Reynolds Jr., R., 1997. X-ray Diffraction and the Identification and Analysis of Clay Minerals, second ed. Oxford University Press, New York, pp. 332.

Musial, G., Reynaud, J.Y., Gingras, M.K., Féniès, H., Labourdette, R., Parize, O., 2012. Subsurface and outcrop characterization of large tidally influenced point bars of the cretaceous McMurray formation (Alberta, Canada). Sediment. Geol. 279, 156-172.

Myers, K.J., Bristow, C.S., 1989. Detailed sedimentology and gamma-ray log characteristics of a Namurian deltaic succession, II: gamma ray logging. In: In: Whateley, M.K.G., Pickering, K.T. (Eds.), Deltas: Sites and Traps for Fossil Fuels, vol. 41. Geological Society, Special Publication, pp. 81-88.

Myers, K.J., Wignall, P.B., 1987. Understanding Jurassic organic-rich mudrocks; new concepts using gamma-ray spectroscopy and palaeo-ecology; examples from the Kimmeridge Clay of Dorset and the Jet Rock of Yorkshire. In: Leggett, J.K., Zuffa, G.G. (Eds.), Marine Clastic Sedimentology; Concepts and Case Studies. Graham \& Trotman, London, pp. 172-189.

North, C.P., Boering, M., 1999. Spectral gamma-ray logging for facies discrimination in mixed fluvial-eolian successions: a cautionary tale. AAPG (Am. Assoc. Pet. Geol.) Bull. 83, 155-169.

Olazábal, S.X., Paredes, J.M., Valle, M.N., Allard, J.O., Foix, N., Tunik, M.A., 2019. Variaciones composicionales de arenitas de la Formación Bajo Barreal en el cerro Ballena (Santa Cruz). In: VII Jornadas de Ciencias de la Tierra Eduardo Musacchio. Comodoro Rivadavia, pp. 21-22.

Olsen, H., 1994. Orbital forcing on continental depositional systems - lacustrine and fluvial cyclicity in the Devonian of East Greenland. In: In: de Boer, P.L., Smith, D.G. (Eds.), Orbital Forcing and Cyclic Sequences. IAS (Int. Ass. Sediment, vol. 19. Special Publication, pp. 429-438.

Olsen, T., Steel, R., Høgseth, K., Røe, S.-L., 1995. Sequential architecture in a fluvial succession: sequence stratigraphy in the upper cretaceous mesaverde Group, price canyon, Utah. J. Sediment. Res. 65, 265-280.

Osmond, J.K., Ivanovich, M., 1992. Uranium-series mobilization and surface hydrology. In: Ivanovich, M., Harmon, R.S. (Eds.), Uranium-series Disequilibrium: Applications to Earth Marine and Environmental Sciences. Clarendon Press, Oxford, pp. 259-289.

Panza, J.L., Haller, M.J., 2002. El volcanismo jurásico. In: In: Haller, M.J. (Ed.), Geología y Recursos Naturales de Santa Cruz. Relatorio del XV Congreso Geológico Argentino. El Calafate, vol. I. pp. 89-101 (Buenos Aires).

Paredes, J.M., Foix, N., Colombo Piñol, F., Nillni, A., Allard, J.O., Marquillas, R.A., 2007. Volcanic and climatic controls on fluvial style in a high-energy system: the lower cretaceous Matasiete Formation, Golfo san Jorge Basin, Argentina. Sediment. Geol. 202, 96-123.

Paredes, J.M., Foix, N., Allard, J.O., Colombo, F., Tunik, M.A., 2015. Alluvial architecture of reworked pyroclastic deposits in peri-volcanic basins: Castillo Formation (Albian) of the Golfo san Jorge basin, Argentina. Rev. Asoc. Geol. Arg. 72, 42-62.

Paredes, J.M., Foix, N., Allard, J.O., 2016. Sedimentology and alluvial architecture of the Bajo Barreal Formation (upper cretaceous) in the Golfo san Jorge basin: outcrop analogues of the richest oil-bearing fluvial succession in Argentina. Mar. Pet. Geol. 72, 317-335.

Paredes, J.M., Foix, N., Allard, J.O., Valle, M.N., Giordano, S.R., 2018a. Complex alluvial architecture, paleohydraulics and controls of a multichannel fluvial system, Bajo Barreal Formation (upper cretaceous) in the cerro Ballena Anticline, Golfo san Jorge Basin, Patagonia. J. South Am. Earth Sci. 85, 168-190.

Paredes, J.M., Aguiar, M., Ansa, A., Giordano, S.R., Ledesma, M., Tejada, S., 2018b. Inherited discontinuities and fault kinematics of a multiphase, non-colinear extensional setting: subsurface observations from the south flank of the Golfo san Jorge basin, Patagonia. J. South Am. Earth Sci. 81, 87-107.

Parkinson, D.N., 1996. Gamma ray spectrometry as a tool for stratigraphical interpretation: examples from the western European Lower Jurassic. In: In: Hesselbo, S.P., Parkinson, D.N. (Eds.), Sequence Stratigraphy in British Geology, vol. 103. Geological Society, Special Publication, pp. 231-255.

Partyka, G., Gridley, J., Lopez, J.A., 1999. Interpretational applications of spectral decomposition in reservoir characterization. Lead. Edge 18, 353-360.

Peroni, G., Hegedus, A., Cerdan, J., Legarreta, L., Uliana, M., Laffite, G., 1995. Hydrocarbon accumulation in an inverted segment of the Andean foreland: san Bernardo belt, central Patagonia. In: In: Tankard, A., Suarez, R., Welsink, H. (Eds.), Petroleum Basins of South America, vol. 62. AAPG (Am. Assoc. Pet. Geol.) Mem., Tulsa, pp. 403-419.

Posamentier, H.W., Davies, R., Wood, L.J., Cartwright, J., 2007. Seismic geomorphologyAn overview. In: In: Davies, R., Posamentier, H.W., Wood, L.J., Cartwright, J. (Eds.), Seismic Geomorphology: Application to Hydrocarbon Exploration and Production, vol. 277. Geological Society of London, Special Publication, pp. 1-20.

Powers, M.C., 1953. A new roundness scale for sedimentary particles. J. Sediment. Petrol. $23,117-119$.

Pranter, M.J., Sommer, M.K., 2011. Static connectivity of fluvial sandstones in a lower coastal-plain setting: an example from the Upper Cretaceous lower Williams Fork Formation, Piceance Basin, Colorado. AAPG (Am. Assoc. Pet. Geol.) Bull. 95, 899-923.

Pranter, M.J., Hewlett, A.C., Cole, R.D., Wang, H., Gilman, J., 2014. Fluvial architecture and connectivity of the Williams Fork Formation: use of outcrop analogues for stratigraphic characterization and reservoir modelling. In: In: Martinius, A.W., Howell, J.A., Good, T.R. (Eds.), Sediment-body Geometry and Heterogeneity: Analogue Studies for Modelling the Subsurface, vol. 387. Geological Society of London, Special Publications, pp. 57-83.

Raucsik, B., Varga, A., 2008. Climato-environmental controls on clay mineralogy of the Hettangian-Bajocian successions of the Mecsek Mountains, Hungary: an evidence for extreme continental weathering during the early Toarcian oceanic anoxic event. Palaeogeogr. Palaeoclimatol. Palaeoecol. 265, 1-13.

Reijenstein, H.M., Posamentier, H.W., Bhattacharya, J.P., 2011. Seismic geomorphology and high-resolution seismic stratigraphy of inner-shelf fluvial, estuarine, deltaic, and marine sequences, gulf of Thailand. AAPG (Am. Assoc. Pet. Geol.) Bull. 95, 1959-1990.

Rider H., M., 1999. The Geological Interpretation of Well Logs. Whittles Publishing Services, Dunbeath.

Rittersbacher, A., Buckley, S.J., Howell, J.A., Hampson, G.J., Vallet, J., 2014. Helicopterbased laser scanning: a method for quantitative analysis of large-scale sedimentary architecture. In: In: Martinius, A.W., Howell, J.A., Good, T.R. (Eds.), Sediment-body Geometry and Heterogeneity: Analogue Studies for Modelling the Subsurface, vol. 387. Geological Society of London, Special Publications, pp. 185-202.

Rodríguez, J.F., 1993. La depositación de las areniscas verdes (Formación Bajo BarrealCretácico Tardío) y sus implicancias tafonómicas. In: 12th Congreso Geológico Argentino and 2nd Congreso de Exploración de Hidrocarburos. Asociación Geológica Argentina, pp. 194-199 (Mendoza).

Ruffell, A.H., Worden, R.H., 2000. Palaeoclimate analysis using spectral gamma-ray data from the Aptian (Cretaceous) of southern England and southern France. Palaeogeogr. Palaeoecol. Palaeoclimatol. 155, 265-283.

Ruffell, A.H., Worden, R.H., Evans, R., 2003. Paleoclimate controls on spectral gammaray radiation from sandstones. IAS Spec. Publ. 34, 93-108.

Sáez, A., Inglès, M., Cabrera, L., de las Heras, A., 2003. Tectonic -palaeoenvironmental forcing of clay-mineral assemblages in nonmarine settings: the Oligocene-Miocene as Pontes Basin (Spain). Sediment. Geol. 159, 305-324.

Sciutto, J.C., 1981. Geología del Codo del Río Senguerr, Chubut, Argentina. In: 8th Congreso Geológico Argentino, Actas, vol. 3. pp. 203-219 (San Luis).

Secretaría de Energía, 2017. Informe estadístico anual 2016 del sector energético. Ministerio de Energía y Minería. Secretaría de Planeamiento Energético Estratégico, pp. 43.

Senkayi, A.L., Ming, D.W., Dixon, J.B., Hossner, L.R., 1987. Kaolinite, opal CT, and clinoptilolite in altered tuffs interbedded with lignite in the Jackson Group, Texas. Clay Clay Miner. 35, 281-290.

Shanley, K.W., McCabe, P.J., 1994. Perspectives on the sequence stratigraphy of continental strata. AAPG (Am. Assoc. Pet. Geol.) Bull. 78, 544-568.

Shoval, S., 2004. Deposition of volcanogenic smectite along the southeastern Neo-Tethys margin during the oceanic convergence stage. Appl. Clay Sci. 24, 299-311.

Šimíček, D., Bábek, O., Leichmann, J., 2012. Outcrop gamma-ray logging of siliciclastic turbidites: separating the detrital provenance signal from facies in the foreland-basin turbidites of the Moravo-Silesian basin, Czech Republic. Sediment. Geol. 262, 50-64.

Simpson, G., Castelltort, S., 2012. Model shows that rivers transmit high-frequency climate cycles to the sedimentary record. Geology 40, 1131-1134.

Slatt, R.M., Jordan, D.W., D'Agostino, A., Gillespie, R.H., 1992. Outcrop gamma-ray logging to improve understanding of subsurface well log correlations. In: In: Hurst, A., Griffiths, C.M., Worthington, P.F. (Eds.), Geological Applications of Wireline Logs II, vol. 65. Geological Society (London) Special Publication, pp. 3-19.

Smith, G.A., 1991. Facies sequences and geometries in continental volcaniclastic sediments. In: In: Fisher, R.V., Smith, G.A. (Eds.), Sedimentation in Volcanic Settings, vol 45. Society of Economic Paleontologists and Mineralogists, pp. 109-121 Special Publication.

Srodon, J., 1984. X-ray powder diffraction identification of illitic materials. Clay Clay Miner. 32, 337-349.

Swanson, F.J., Collins, B., Dunne, T., Wicherski, B.P., 1982. Erosion of tephra from hillslopes near Mt. St. Helens and other volcanoes. In: Proceedings of the Symposium on Erosion Control in Volcanic Areas, Public Works Research Institute, vol. 1908. 
Technical Memorandum, Japan, pp. 183-221.

Tandon, S.K., Sinha, R., 2007. Geology of large river systems. In: Gupta, A. (Ed.), Large Rivers: Geomorphology and Management. John Wiley \& Sons, pp. 7-28.

Thiry, M., 2000. Palaeoclimatic interpretation of clay minerals in marine deposits: an outlook from the continental origin. Earth Sci. Rev. 49, 201-221.

Tunik, M.A., Paredes, J.M., Fernandez, M.I., Foix, N., Allard, J.O., 2015. Análisis petrográfico de areniscas de la Formación Castillo (Albiano) en la faja plegada de San Bernardo, Cuenca Golfo San Jorge, Argentina. Rev. Asoc. Geol. Arg. 72, 63-80.

Umazano, A.M., Bellosi, E.S., Visconti, G., Melchor, R.N., 2008. Mechanism of aggradation in fluvial systems influenced by explosive volcanism: an example from the upper cretaceous Bajo Barreal Formation, san Jorge basin, Argentina. Sediment. Geol. 203, 213-228.

Umazano, A.M., Bellosi, E.S., Visconti, G., Jalfin, G.A., Melchor, R.N., 2009. Sedimentary record of a late cretaceous volcanic arc in central Patagonia: petrography, geochemistry and provenance of fluvial volcaniclastic deposits of the Bajo Barreal Formation, san Jorge basin, Argentina. Cretac. Res. 30, 749-766.

Umazano, A.M., Bellosi, E.S., Visconti, G., Melchor, R.N., 2012. Detecting allocyclic signals in volcaniclastic fluvial successions: facies, architecture and stacking pattern from the Cretaceous of central Patagonia, Argentina. J. South Am. Earth Sci. 40, 94-115.

Uliana, M.A., Biddle, K.T., Cerdán, J., 1989. Mesozoic extension and the formation of
Argentine sedimentary basins. In: In: Tankard, A.J., Balkwill, H.R. (Eds.), Extensional Deformation and Stratigraphy of the North Atlantic Margins. AAPG, vol. 46. Am. Assoc. Pet. Geol.) Mem., Tulsa, pp. 599-614.

Vallati, P., Casal, G., Foix, N., Allard, J.O., De Sosa Tomás, A., Calo, M., 2016. First report of a maastrichtian palynoflora from the Golfo san Jorge basin, central Patagonia, Argentina. Ameghiniana 53 (4), 495-505.

Weaver, C.E., 1989. Clays, muds, and shales. In: Developments in Sedimentology, vol. 44. Elsevier, Amsterdam, pp. 819.

Wilson, M.J., 1999. The origin and formation of clay minerals in soils: past, present and future perspectives. Clay Miner. 34, 7-25.

Wood, L.J., 2007. Quantitative seismic geomorphology of Pliocene and Miocene fluvial systems in the northern Gulf of Mexico. J. Sediment. Res. 77, 713-730.

Worden, H., Morad, S., 2003. Clay minerals in sandstones. In: In: Worden, H., Morad, S. (Eds.), Minerals Cements in Sandstones, International Association of Sedimentologists, Special Publication, vol. 34. Blackwell Publishing Ltd, Oxford, UK, pp. 3-41.

Wright, V.P., Marriott, S.B., 1993. The sequence stratigraphy of fluvial depositional systems: the role of floodplain sediment storage. Sediment. Geol. 86, 203-210.

Zuffa, G.G., 1985. Optical analyses of arenites: influence of methodology on compositional results. In: Provenance of Arenites. Springer, Netherlands, pp. 165-189. 